\title{
Article \\ The Impact of Israeli and Saudi Arabian Geopolitical Risks on the Lebanese Financial Market
}

\author{
Layal Mansour-Ichrakieh
}

Citation: Mansour-Ichrakieh, Layal. 2021. The Impact of Israeli and Saudi Arabian Geopolitical Risks on the Lebanese Financial Market. Journal of Risk and Financial Management 14: 94. https://doi.org/10.3390/jrfm14030094

Academic Editor: Vanja Piljak

Received: 1 December 2020

Accepted: 1 February 2021

Published: 28 February 2021

Publisher's Note: MDPI stays neutra with regard to jurisdictional claims in published maps and institutional affiliations.
Department of Economics, Lebanese American University, Beirut 1102, Lebanon; layal.ichrakieh@lau.edu.lb

\begin{abstract}
Hezbollah is best defined in geopolitics as the Iranian ideology proxy that aims to grow the Persian footprint and to gain geopolitical strategic depth in the region. Its role continuously requires geopolitical conflicts, mainly against Saudi Arabia and Israel—for resistance, ideological, and geopolitical purposes. Being a state within a state, Hezbollah militia makes sovereign geopolitical decisions and forces Lebanon to pay for the consequences. This is the first economic study that empirically investigates under vector autoregression (VAR) models the dynamic causal relationship between Saudi Arabia and Israel's geopolitical risks and Lebanon's financial stability and economic activity. The results show that Saudi Arabia and Israel's geopolitical risks affect Lebanon's economy differently. Economic and financial stability cannot be promoted independently of regional geopolitical conflict.
\end{abstract}

Keywords: financial stress index; geopolitical risks; Granger causality VAR; Hezbollah; Israel; Saudi Arabia; Lebanon

\section{Introduction}

The Middle East and North Africa region is currently witnessing changes toward the deal of the century. It is promoted by Israel's normalization with many Arab countries such as the United Arab Emirates, Bahrain, Sudan, Qatar, and Morocco (and probably Saudi Arabia and Oman). Despite the historical maritime border talks between Lebanon and Israel that have started in October 2020 (and still ongoing), its success is not guaranteed. In fact, it is extremely challenging to predict geopolitical changes in Lebanon under Hezbollah's domination.

\subsection{Hezbollah, Israel, and Saudi Arabia: Geopolitical Background}

Founded in 1982 by Iran, Hezbollah's - the Islamic resistance army-mission was exclusively to liberate the Israeli occupation of southern Lebanon. Paradoxically, in May 2000, when the Israeli military army withdrew from Lebanon, Hezbollah "theoretically" lost the legitimacy to keep its weapons (UNSCOL [2004] 2006). For that, Hezbollah had to wear many hats, all under the resistance umbrella: it positioned itself as a resistant militia (1) to defend the Palestinian cause against Israel, (2) to protect southern Lebanon from future Israeli attacks, and (3) to weaken Saudi Arabia's regional influence for ideological rivalry. Regardless of its declared resistance agenda, Hezbollah is nothing but Iran's proxy that behaves at its behest (DeVore 2012; Seliktar and Rezaei 2020) to gain geopolitical-strategic depth in the region.

Since ideology, civilization, religion, and geopolitics appear complementary (Kuçi 2020; Sheikh 2003). Hezbollah had to accumulate an array of sophisticated armaments, rockets, and weapons. It has also expanded tens of thousands of trained fighters in order to spread ideological-Welayat Al-Faqih — ethnic grounds far and wide (Salamey and Othman 2011; Al-Aloosy 2020) no matter the devastation caused, as long as it increases the Persian footprint (Haddad 2006; Jones 2019). Yemen, Iraq, and Syria are testimonies of the poverty, starvation, corruption, and terrorism caused by Hezbollah's invasion under 
different military group names to control territory, natural resources, or other important geographical positions or places (Friedman 2018).

Being heavily armed, Hezbollah could successfully become deeply embedded within the sociopolitical structures of Lebanon may (May 2020; Wiegand 2009) or more precisely, it becomes the de facto policy decision-maker (Worrall et al. 2015; Norton 2007). For instance, in May 2008, because the Lebanese government decided to dismantle Hezbollah's military communications network, Hezbollah turned its weapons inward toward Beirut (the capital of Lebanon), against pro-government civil people and gunmen. They killed 18 people and injured 38 in three days of battles before the government gave up.

\subsection{Lebanon and Hezbollah: From the Best of Friends to the Best of Enemies}

Hezbollah's domination is not limited to affecting the Lebanese sovereignty, but it also has a deleterious effect socially, economically, and globally. In fact, Hezbollah abuses its military and political "superpowers" to violate Lebanese laws, human rights, and even international laws such as United Nations Security Council Resolutions 1559 and 1701 (UNSCOL [2004] 2006). Moreover, it announces explicitly through official speeches that it has proud recourse to illegal and criminal activities: corruption, bribery, financial transaction, money laundering, and tax evasion that has exceeded 10 percent of GDP in 2017 (Blom-Bank 2017), with a Tax Evasion Index of 0.69, as estimated by Vo et al. (2020). Additionally, Hezbollah is the leader in smuggling, human trafficking, and production and trafficking of drugs (Badran and Ottolenghi 2020). With that being said, Hezbollah has earned, with merit, its listing as a terrorist organization/military wing by more than 65 countries government (United.States.Government 2019, 2021). Expectedly, Lebanese politicians and institutions are continually undergoing US sanctions from The Global Magnitsky Human Rights Accountability and the Office of Foreign Assets Control accused of having contributed, directly or indirectly, to Hezbollah's illegal activities.

\subsection{Research Question and Hypothesis}

The consequences of Hezbollah's underground activities and geopolitical tensions are bore by Lebanon (the country). It would be valuable to assess empirically the impact of Saudi Arabian and Israeli geopolitical threats with Hezbollah on the Lebanese financial market. It goes back to 1997 when Schrodt (1997) tried to create an early warning indicator of geopolitical risks between Israel and Hezbollah (in the south of Lebanon) to forecast future conflict and to help policymakers avoid financial crises. However, his study lacks precision due to data limitations.

Although the literature is abundant in political science regarding Lebanese geopolitics, it remains rare, if not inexistant, in economics and econometrics. Instead, studies are rather press releases, newspaper articles, or economic reports elaborated by the United Nations, Reuters, the World Bank, or other international organizations. These publications are somehow descriptive and merely limited to estimating the cost of reconstruction (after a war) or to exposing in value the costs and losses of geopolitical conflicts on education, welfare, agriculture, and employment.

This paper aims to investigate empirically-on a monthly basis, from June 2000 (after Lebanon deliberation) to November 2018 - the dynamic causality-independence between geopolitical risks of Israel and Saudi Arabia (towards Hezbollah) and the Lebanese financial market.

This study employs Granger causality tests under vector autoregression (VAR) models, followed by first—orthogonalize-Cholesky decomposition-impulse response functions and variance decomposition of variables to detect the dynamic relations between Israeli and Saudi Arabian geopolitical risks with the Lebanese financial market and economic activity.

This study aims to achieve one of two possible conclusions:

If the Lebanese financial market shows independency or low dependency-causality to the regional geopolitical risks, then Hezbollah's geopolitical tensions with Israel and Saudi Arabia do not seem to negatively affect the Lebanese financial stability. Consequently, 
economic reforms, monetary and fiscal policies, as well as internal legal reforms can be improved independently from the geopolitical, international, and diplomatic arrangements.

If the Lebanese financial market shows significant dependency-causality to the regional geopolitical risks, then Hezbollah's tensions with Israel and Saudi Arabia trigger the Lebanese financial stability and economic activity. Therefore, instead of solving the Lebanese economic crisis from a purely economic perspective, measures towards negotiation and conflict resolution with the neighborhood are needed, which require de-Hezbollizing Lebanon.

One would find it evident that geopolitical risks negatively affect the financial stability and economic activity; however, the literature shows different conclusions depending on the country's category, income level, and even polity.

The remainder of the paper is structured as follows: Section 2 includes a literature review. Section 3 describes the data and statistical tests. Section 4 illustrates the graphical analysis with preliminary deductions. Section 5 exposes the methodology. Section 6 interprets and discusses results and findings. Section 7 closes with a conclusion and recommendations.

\section{Literature Review}

Analyzing Geopolitical Risks' (GPR) economic consequences remains essential for policymakers, portfolio managers, firms, and international institutions to update their forecasting and risk assessment efforts (Hendrix 2019). Accordingly, to predict political behavior phases during conflicts in the Middle East region, Schrodt and Gerner $(1997,2004)$ tried to elaborate a geopolitical early-warning indicator, using several statistical techniques. With the upsurge in terrorist attacks, regional wars, and new form of collective violence, a growing number of scholarly interests focus on assessing geopolitical risks' (GPRs) impacts and consequences.

\subsection{Geopolitical Risks and Economic Activity}

Some of the literature empirically examines the GPR's impact on per capita GDP growth. For instance, Eckstein and Tsiddon (2004) used vector autoregressive (VAR) models to study the impact of geopolitical risks on the economy. They found a significant negative impact on GDP per capita that exceeds $2 \%$ in some countries, such as Israel. According to Tavares (2004), geopolitical risks, or more precisely terrorism, may have a small negative impact on per capita GDP growth. However, his findings become insignificant once he has added determinants of growth, such as education, trade openness, and inflation rate. Unlike Tavares (2004) findings, Gupta (2008) reported that country risk does not seem to negatively affect per capita income growth in low- and middle-income countries but rather has an indirect negative impact on the economic growth by increasing the defense-spending share of the government.

Several scholars examined the impact of GPR on the economic activity (Cepni et al. 2020; Saint Akadiri et al. 2020; Cheng and Chiu 2018). They employed structural VAR models and time-varying multivariate causality and then concluded that the geopolitical shocks in the emerging countries are associated with significant economic contractions.

Instead of exploring economic growth response to GPR shocks, a wide array of studies rather focuses on breaking down the economic activity and examining its sectors' and/or components' response to GPR shocks. For instance Gupta et al. (2019) verified the impact of GPR on trade flows. They considered GPR in a gravity model, with fixed effect-random effect, Hausman Taylor, and Poisson Pseudo-Maximum Likelihood, and then, they found that GPR negatively affects the trade flows.

Saint Akadiri et al. (2020) studied the impact of geopolitical risks on the touristic sector and the GDP growth in Turkey. Using Toda-Yamamoto's version of the Granger causality, he founds a unidirectional causality running from geopolitical risk index to economic growth and from geopolitical risk index to tourism. Other researchers examined specifically the terrorism impact (among other geopolitical component variables) on the 
touristic sector in the long run and the short run. A. Liu and Pratt (2017) considered the global terrorism index to analyze the relationship between terrorism and tourism in 95 countries using the autoregressive distributed lag (ARDL) model. They found that, in the long run, for the large majority of destinations, terrorism has a minimal impact on tourism demand (except for nine countries out of 95). However, significant short-run impacts of terrorism were found in 25 individual destinations including Israel and Turkey. Similarly, Karamelikli et al. (2020) used a nonlinear ARDL impact of terrorism on the incoming and domestic tourism in Turkey. They found that terrorism affects differently the inbound and domestic tourists in the long run and in the short run.

According to Hamadeh and Bassil (2017), who studied the impact of terrorism on the touristic sector in Lebanon, European tourists appear to be less sensitive to terrorist attacks than Arab tourists.

Seabra et al. (2020) concluded that terrorist attacks in one country can have a positive or a negative impact on the touristic sector in other countries. For instance, terrorist attacks that take place in Israel and Greece seem to negatively affect tourist arrivals from Africa in Portugal, while attacks perpetrated in other countries positively influence arrivals in the country.

Additionally, researchers such as Eckstein and Tsiddon (2004) and Sandler and Enders (2008) examined the way GPR's tendencies varied in different categories of countries. They demonstrated that the causality between geopolitical risks and economic growth depends on the economy's type. In other words, the economic activity of developed, emerging, and developing countries respond to GPR shocks differently. Furthermore, Das et al. (2019) tested the dynamic causality of GPR on macroeconomic variables, using threshold VAR models and found several shock impacts across different market states. Similarly, Tavares and Wacziarg (2001) and Tavares (2004) advocated the asymmetric impact of GPR among economies. By comparing the costs of terrorism in democratic versus non-democratic countries, they found that a higher level of democracy could act as a buffer against terrorist attacks and could better recover from the GPRs.

\subsection{Geopolitical Risks and the Financial Market}

Economists argue about GPR measurement, which lacks accuracy in econometricempirical studies. In fact, similar to in politics, variables in geopolitics that represent social-human behavior are rather qualitative. They are available only for a few years and are usually binary-discrete (i.e., reported with numbers ranging from one to five or with very little variability). In 2018, Caldara and Iacoviello (2018) constructed a revolutionary GPR index, a more developed version of the GPR index previously elaborated by Chadefaux (2014), Saiz and Simonsohn (2013) and Baker et al. (2016), best conceived in time series analysis. It is a continuous index (rather than discrete), which is delivered on a monthly basis, since 1985. Since the new GPR was launched in 2018, researchers' appetites to examine and empirically assess the relationship between the GPR and the financial-stock market has jumped significantly. Das et al. (2019) approved of this index being more specialized. It captures specific events and is expected to have an explicit impact on the financial variables.

Accordingly, Apergis et al. (2018), Bouras et al. (2019), and Lee (2019) verified the GPR impact on stock market volatility, using Granger causality tests, panel generalized autoregressive conditional heteroskedasticity (GARCH), and the copula approach, respectively. They found an overall significant positive impact with minor differences that are related to the model or the countries' details. Mansour-Ichrakieh and Zeaiter (2019) also investigated the dynamic causality between Saudi Arabia and Russia's GPRs on the Turkish financial market. Using threshold VAR, they found that the Turkish financial market is more sensitive to Saudi GPR and can even change the financial market's state from low-stress level to high-stress level. Bouoiyour et al. (2019) employed a flexible Markovswitching dynamic copula approach to examine the dynamic response of the oil market as a 
nonlinear-switching phenomenon to geopolitical risks in different scenarios: low and high risks. They found that oil price appears to respond to GPR shocks strongly and positively.

Similarly, Plakandaras et al. (2019) and J. Liu et al. (2019) verified the GPR causality on oil prices and the financial liquidity by running dynamic model averaging, a means of wavelet analysis, on Saudi Arabia and by employing GARCH and Mixed Data Sampling model (MIDAS). They found an overall similar conclusion (with minor changes in each study), that the oil price and the domestic liquidity seem to respond to GPR shocks. Likewise Cunado et al. (2020) employed a time-varying parameter structural VAR model to verify the dynamic relationship between GPR and oil price in the Middle East. They confirmed that higher GPR shocks drive the oil prices upwards. As for Al-Yahyaee et al. (2019) and Aysan et al. (2019), they focused on analyzing bitcoin's value responsiveness (return or volatility) to GPR. By using a bivariate and multivariate wavelet approach and Bayesian Graphical Structural VAR technique, respectively, a positive relation was revealed.

The present paper empirically investigates, for the first time, the impact of Israeli and Saudi Arabian geopolitical risks (toward Hezbollah) on the Lebanese financial market stability and economic activity.

\section{Data and Statistics}

This section breakdowns all variables needed to investigate the dynamic relationship between GPRs of Israel and Saudi Arabia and the Lebanese financial market and economic activity.

\subsection{Data}

Data are reported on a monthly basis from June 2000 to November 2018 and in percentage growth. Their growth-pattern time-series are reported in Figure 1.

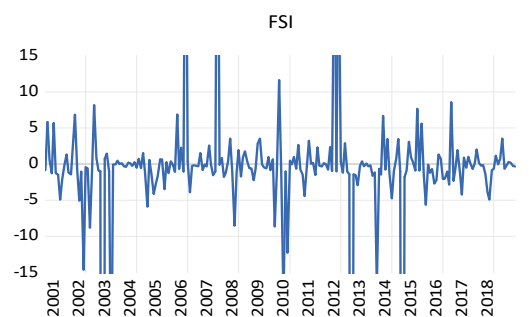

FXFXD

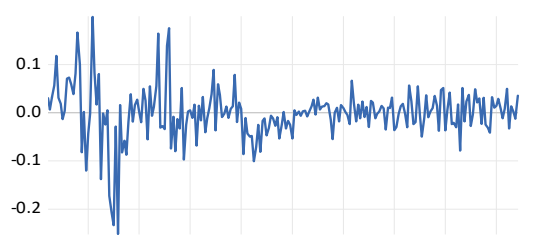

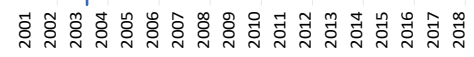

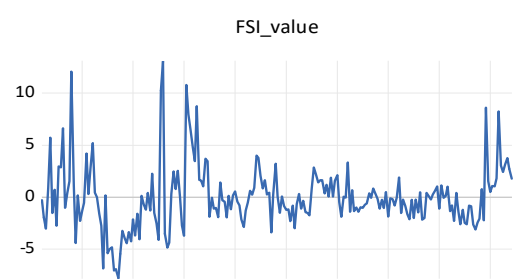

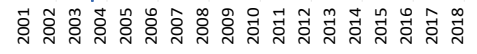

gpr_israel

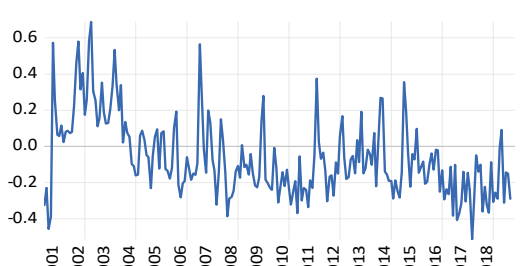

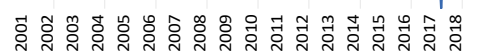

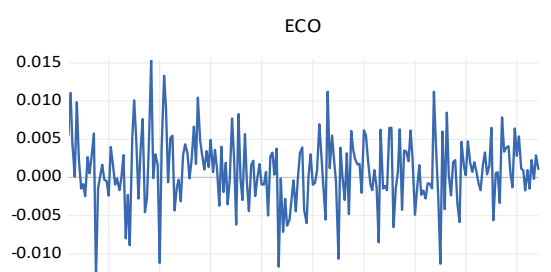

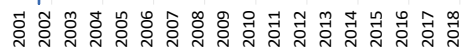

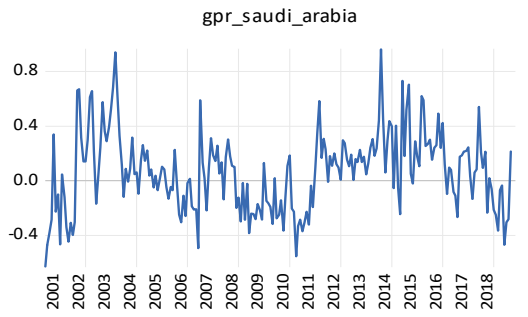

Figure 1. Growth pattern of variables.

All variables are taken in growth pattern. Positive fluctuations indicate high financial stress, high geopolitical threat periods, depletion of Foreign reserves (FX), or economic recession, while negative fluctuations indicate the opposite. Covariance stationarity is observed graphically. However, traditional tests such as Augmented Dickey Fuller (ADF) and Phillips-Perron (PP) tests are needed to verify the stationarity of variables.

\subsubsection{The Financial Stress Index (FSI)}

Through the literature, the Financial Stress Index (FSI) is the most common index used to empirically test the dynamic relationship with economic variables. The Lebanese FSI follows the methodology of Cardarelli et al. (2009) and Balakrishnan et al. (2011), but it is developed and tailored by adding the dollarization rate to better represent a dollarized 
country (Ishrakieh et al. 2020b, 2020a). It includes the main early warning indicators of each of the banking sector, the stock or equity market, and the foreign exchange and debt markets. It was constructed by on a monthly basis from January 1998 to January 2018 but has not been employed econometrically yet (the FSI data are available online at https: / / data.mendeley.com/datasets/sc7hmvcmjf/2, accessed on 1 December 2020).

The present paper studies the period after the complete Israeli withdrawal from occupied territories (from June 2000). The FSI is modified by removing the weighted average cost of capital and the inverted yield because their weights are zero. The FSI is updated to November 2018 and data are available online with this study. The FSI does not include any structural breaks, not even during the 2008-global subprime crisis, since the crises transmission channels through the equity market or via the exchange rate are insignificant (the de facto Lebanese pound is not floating but pegged to dollar). Moreover, the equity market is relatively tiny. The most informative market in Lebanon that fluctuates with panic of economic agents remains the foreign and exchange markets.

\subsubsection{Business Cycle}

There are several techniques to determine and define the business cycle as Škare and Stjepanović (2016) illustrate in a comparative table. Most researchers (Balakrishnan et al. 2011; Cardarelli et al. 2009; Cevik et al. 2016; Davig and Hakkio 2010) consider the business cycle that follows the Harding and Pagan (2002) methodology. In Lebanon, the business cycle is determined by Jad (2017), following the Bry and Boschan (1971) methodology.

\subsubsection{Economic Activity (ECO)}

The Industrial Production Index (IPI) and the Gross Capital Stock (GCS) are the most used in the literature as a proxy of the Gross Domestic Product (GDP) (Kaminsky and Reinhart 2002; Reinhart and Rogoff 2009; Demetriades et al. 2017). In Lebanon, all of the GDP, IPI, and GCS data are available on a yearly basis and/or for a few years. Accordingly, in the present study, employment in the private sector was taken as a proxy for economic business cycles or economic activity (ECO). Table 1 exhibits the correlation between GDP, GSC, and ECO that is reported on a yearly basis and seasonally adjusted by the Federal Reserves-Saint Louis. The ECO sign is inverted so positive values indicate economic contraction and vice versa.

Table 1. GDP, capital stock, and employment private sector correlation with GDP (annual).

\begin{tabular}{cccc}
\hline Variables & $\begin{array}{c}\text { Capital Stock Mill } \\
\text { USD }\end{array}$ & $\begin{array}{c}\text { Employment in } \\
\text { Private Sector in } \\
\text { Thousands of People }\end{array}$ & GDP Mill USD \\
\hline $\begin{array}{c}\text { Capital Stock Mill } \\
\text { USD }\end{array}$ & $100 \%$ & $76.4 \%$ & $96.5 \%$ \\
$\begin{array}{c}\text { Employment in } \\
\text { Private Sector }\end{array}$ & $76.4 \%$ & $100 \%$ & $88.71 \%$ \\
GDP Mill USD & $96.5 \%$ & $88.71 \%$ & $100 \%$ \\
\hline
\end{tabular}

The correlation between employment in the private sector and the constant GDP reaches 88 percent. Since in Lebanon monthly data of GDP, IPI, and GSC are unavailable, employment in the private sector that is calculated on a monthly basis is taken as a proxy for GDP to express the economic activity.

\subsubsection{Geopolitical Risks (GPR)}

The Geopolitical Risk (GPR) index is taken from Caldara and Iacoviello (2018). It is a continuous variable (rather than discrete) normalized to 100 and reported on a monthly basis, from 1985 to September 2018 (The index was last time updated in November 2019 and is available on https:/ / www.matteoiacoviello.com/gpr.htm, accessed on 1 December 2020). It is elaborated from various newspaper articles covering geopolitical tensions and examining the evolution and effects that best reflect geopolitical risks, military-related tensions, nuclear tensions, war threats, terrorist threats, and the beginning of war. The GPR index also encompasses mass-social media and messages delivered through TV speeches, 
interviews, newspapers, and other media campaigns. It is elaborated for many developed and emerging countries.

\subsubsection{The Adequate Level of Foreign Reserves in a Dollarized Country (FXFXD)}

The innovative character of this study's data is in the choice of the adequate level of FX, that best suits a dollarized country like Lebanon. All previous studies investigating Lebanon or including Lebanon in a panel with other countries use general measurements of FX (such as the FX to gross domestic product ratio, or the FX to broad money ratio, or the FX to import ratio, or the FX to short-term external debt ratio). More often, researchers consider the Guidotti-Greenspan Rule, that measures total foreign reserves over short-term external debt. Although considered the rule of thumb, the Guidotti-Greenspan Rule lacks accuracy in a dollarized country. In fact, Gonçalves (2008), Soto and García (2004), Durdu et al. (2009), and Calvo et al. (2008) found that the money demand in foreign currency of a dollarized country is highly correlated with the sudden stop and the systemic crises. In the 2017-IMF country report for Lebanon, Ahuja et al. (2017) stated that "A common shock to bank liquidity, leading to a demand for foreign currency, could result in a drop in international reserves (1 percent of deposits are equivalent to 3.7 percent of reserves)". Accordingly, a more adequate level of FX is suggested by Gonçalves (2008) which is the ratio of FX to Deposit in Foreign Currency (FXFXD). Data are taken from the central bank of Lebanon. The FXFXD sign was inverted, so an increase in the ratio becomes a threat.

\subsection{Statistics}

Descriptive statistics and correlations of variables are reported in Tables 2 and 3.

Table 2. Variable correlations.

\begin{tabular}{cccccc}
\hline Variables & ECO & FSI & FXFXD & GPR Israel & $\begin{array}{c}\text { GPR Saudi } \\
\text { Arabia }\end{array}$ \\
\hline ECO & $100 \%$ & $-10.76 \%$ & $-3.71 \%$ & $-1.03 \%$ & $-2.75 \%$ \\
FSI & $-10.76 \%$ & $100 \%$ & $6.02 \%$ & $-12.85 \%$ & $-17.24 \%$ \\
FXFXD & $-3.71 \%$ & $6.02 \%$ & $100 \%$ & $-0.43 \%$ & $-4.17 \%$ \\
GPR Israel & $-1.03 \%$ & $-12.85 \%$ & $-0.43 \%$ & $100 \%$ & $47.64 \%$ \\
GPR Saudi Arabia & $6 \%$ & $-10 \%$ & $-11 \%$ & $-11 \%$ & $100 \%$ \\
\hline The table indicates that variables are not strongly correlated.
\end{tabular}

Table 3. Descriptive statistics.

\begin{tabular}{ccccccc}
\hline Variables & ECO & FSI & FSI Value & FXFXD & $\begin{array}{c}\text { GPR } \\
\text { Israel }\end{array}$ & $\begin{array}{c}\text { GPR Saudi } \\
\text { Arabia }\end{array}$ \\
\hline Mean & 0.00 & -2.05 & -0.05 & 0.00 & -0.06 & 0.06 \\
Median & 0.00 & -0.41 & -0.21 & 0.00 & -0.12 & 0.08 \\
Maximum & 0.01 & 54.74 & 13.07 & 0.20 & 0.69 & 0.96 \\
Minimum & -0.02 & -250.68 & -7.75 & -0.25 & -0.51 & -0.63 \\
Std. Dev. & 0.00 & 21.64 & 3.04 & 0.05 & 0.22 & 0.29 \\
Skewness & 0.09 & -8.36 & 1.19 & -0.53 & 0.95 & 0.33 \\
Kurtosis & 3.93 & 89.66 & 6.61 & 8.00 & 3.86 & 3.11 \\
Jarque-Bera & 8.20 & $71,397.89$ & 171.91 & 239.33 & 39.53 & 4.04 \\
Probability & 0.02 & 0.00 & 0.00 & 0.00 & 0.00 & 0.13 \\
Sum & -0.20 & -451.54 & -10.94 & -0.24 & -13.66 & 13.88 \\
Sum Sq. Dev. & 0.00 & $102,513.50$ & 2022.37 & 0.66 & 10.21 & 18.09 \\
Observations & 220 & 220 & 220 & 220 & 220 & 220 \\
\hline
\end{tabular}

\section{Graphical Analysis and Preliminary Deductions}

It appears common that the aforementioned authors interpret graphically the FSI spikes with the business cycle before proceeding with empirical models. FSI fluctuations are represented in Figure 2. Recession periods are reported in the shaded areas. 


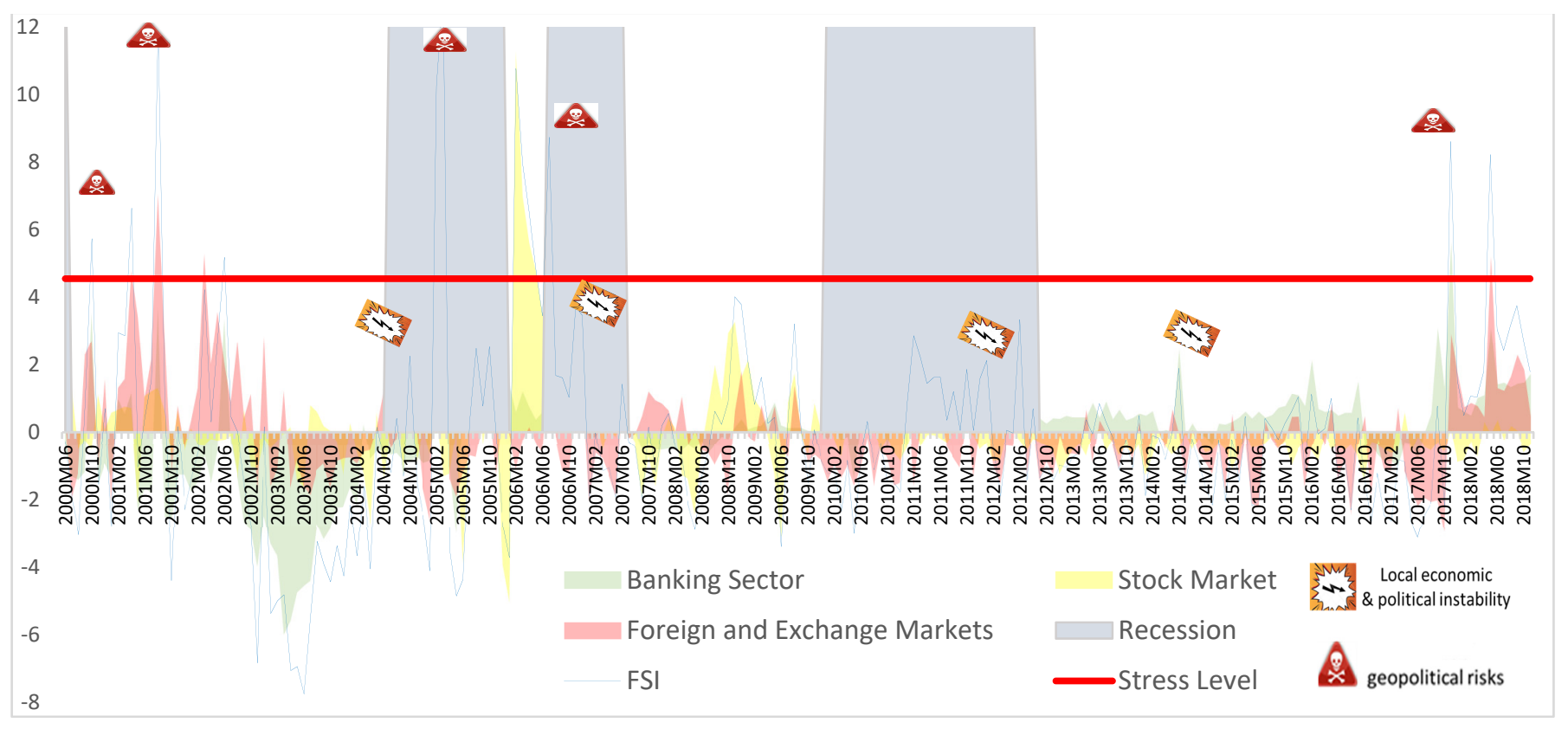

Figure 2. The recession periods, the FSI and the FSI's sectors. Source: the author's calculations and elaboration. Data are available with the paper.

High fluctuations that are reported in positive values indicate stressful periods/financial crises, while low fluctuations reported in negative values indicate low stress periods. The stress level is represented by 1.5 times the standard deviation of the FSI.

Graphical analysis shows that most of the economic and political trouble trigger FSI at a low level (below the stress level). They are mainly triggered by credit rating downgrading (in May 2008, February 2011, May 2012, November 2013, December 2014, and September 2015); by the central bank's interventions through financial engineering (in May and August 2016 and in September 2017); or by internal political trouble such as conflict between political parties, government members' resignation (January 2011, February 2015), or election delays (2014-2016).

On the other hand, most FSI high spikes that surpass the stress level seem to be associated with regional geopolitical threats. For instance, the dates April and October 2000, April 2001, and July 2006 detect tensions with Israel. In July 2006, few years after the IsraelLebanon ceasefire, Lebanon faced a one-month-destructive war with Israel. Nevertheless, Israel responded to Hezbollah attacks (Sharp et al. 2006) rather than attacking Lebanon. It is stated in Schmitt (2007) that "Israel did not attack the government of Lebanon, but rather Hizbullah military assets within Lebanon".

The two most severe financial crises with the highest spike levels were hit in February 2005 when the Lebanese prime minister named Hariri was assassinated and in November 2017 when the Lebanese prime minister, Hariri Junior, was detained in Saudi Arabia and was forced to resign. In appearance, these dates seem to be caused by internal political trouble. In reality, the Hezbollah is in the details: In October 2020, the Special Tribunal for Lebanon-United Nations Security council resolution 1757 declared that the prime minister was assassinated in February 2005 by a terrorist attack from a member of Hezbollah. Similarly, in November 2017, Saudi Arabia detained the prime minister as an expression of its disagreement toward Hariri Junior's cooperation with the Hezbollah political party.

The graphical analysis presumes that high FSI spikes are related to the regional geopolitical tensions with Hezbollah whereas local political or economic pressures are not. Similarly, it appears that most of the recession periods overlap positive high FSI spikes. Nevertheless, empirical tests are crucial to verify the preliminary deductions. 


\section{Methodology}

VAR is a natural framework for examining Granger causality, commonly employed by macroeconomists to characterize the joint dynamic behavior of variables such as geopolitical risks with other macroeconomic variables. Similarly, Impulse-Response Functions measure the dynamic marginal effects of each shock on all of the variables over time. Finally, the variance decompositions examine how important each of the shocks is a component of the overall (unpredictable) variance of each of the variable over time.

\subsection{Preliminary VAR Steps}

VAR times-series analysis first requires verifying that all variables are stationary then choosing the appropriate lag length criteria.

\subsubsection{Stationarity}

Variable stationarity is tested with Augmented Dickey Fuller (ADF) and PhillipsPerron (PP). The results are reported in Table 4.

Table 4. Stationarity test: Augmented Dickey Fuller (ADF) and Phillips-Perron (PP).

\begin{tabular}{|c|c|c|c|c|c|c|c|}
\hline \begin{tabular}{|ll} 
& Tests \\
Variables &
\end{tabular} & $\begin{array}{c}\mathrm{T}-\text { Stat } \\
\text { and Prob }\end{array}$ & $\begin{array}{c}\text { ADF } \\
\text { Intercept }\end{array}$ & $\begin{array}{l}\text { ADF Intercept } \\
\text { and Trend }\end{array}$ & ADF None & $\begin{array}{c}\mathrm{PP} \\
\text { Intercept }\end{array}$ & $\begin{array}{l}\text { PP Trend and } \\
\text { Intercept }\end{array}$ & PP None \\
\hline \multirow{2}{*}{ GPR Saudi Arabia } & $\mathrm{T}-$ Stat & -7.63 & -7.62 & -7.36 & -7.46 & -7.45 & -7.22 \\
\hline & Prob & 0.019 & 0.00 & 0.0036 & 0.00 & 0.00 & 0.00 \\
\hline \multirow{2}{*}{$\mathrm{ECO}$} & $\mathrm{T}-$ Stat & -14.41 & -14.39 & -13.9 & -14.41 & -14.38 & -13.93 \\
\hline & Prob & 0.00 & 0.00 & 0.00 & 0.00 & 0.00 & 0.00 \\
\hline \multirow{2}{*}{ FSI } & $\mathrm{T}-$ Stat & -14.07 & -14.82 & -14.73 & -14.83 & -14.82 & -14.73 \\
\hline & Prob & 0.00 & 0.00 & 0.00 & 0.00 & 0.00 & 0.00 \\
\hline \multirow{2}{*}{ FXFXD } & $\mathrm{T}-$ Stat & -7.26 & -7.25 & -7.27 & -11.86 & -11.84 & -11.88 \\
\hline & Prob & 0.00 & 0.00 & 0.00 & 0.00 & 0.00 & 0.00 \\
\hline \multirow{2}{*}{ GPR Israel } & $\mathrm{T}-$ Stat & -6.98 & -8.43 & -6.68 & -8.43 & -6.39 & -12.38 \\
\hline & Prob & 0.00 & 0.00 & 0.00 & 0.00 & 0.00 & 0.00 \\
\hline
\end{tabular}

The null hypothesis for ADF and PP tests states that the variable has a unit root. The table's results reject for all the series at the $1 \%$ level, the null hypothesis. Thus, variables are stationary and suitable for further statistical or time-series analyses.

\subsubsection{Lag Length Criteria}

The literature analyzing the choice of the appropriate VAR lag length criteria is vast. However, the aforementioned authors (Cf. section literature review) have chosen the traditional Akaike Information Criterion suggested by Akaike.

The lag order selection criteria of the sequential modified (LR) test statistic, the Final Prediction Error (FPE), Schwarz information Criterion (SC), Hannan-Quinn information criterion (HQ), and the Akaike Information Criterion (AIC) are reported in Tables 5-8.

Table 5. Length criteria: ECO, FSI, and FXFXD.

\begin{tabular}{ccccccc}
\hline Lag & LogL & LR & FPE & AIC & SC & SC \\
\hline 0 & 212.8025 & NA & 0.0000283 & -1.960771 & -1.913584 * & $-1.913584^{*}$ \\
1 & 223.3274 & 20.65639 & 0.0000279 & -1.975022 & -1.786276 & -1.786276 \\
2 & 237.7299 & 27.86275 & $0.0000265 *$ & $-2.025513 *$ & -1.695207 & -1.695207 \\
3 & 242.1468 & 8.420967 & 0.0000276 & -1.98268 & -1.510814 & -1.510814 \\
4 & 250.9603 & 16.55623 & 0.0000277 & -1.980937 & -1.367512 & -1.367512 \\
5 & 252.6416 & 3.111287 & 0.0000297 & -1.912538 & -1.157553 & -1.157553 \\
6 & 265.2655 & $23.00618 *$ & 0.0000287 & -1.946407 & -1.049862 & -1.049862 \\
7 & 268.6811 & 6.128865 & 0.0000303 & -1.894216 & -0.856111 & -0.856111 \\
8 & 274.5715 & 10.40465 & 0.0000312 & -1.865155 & -0.68549 & -0.68549 \\
\hline
\end{tabular}

* lag order selected by the criterion. Sample: 2000M06 2018M11. Included observations: 212. 
Table 6. Lag length criteria: GPR Israel, GPR Saudi Arabia, FSI, and FXFXD.

\begin{tabular}{ccccccc}
\hline Lag & LogL & LR & FPE & AIC & SC & HQ \\
\hline 0 & -609.7302 & NA & 0.003843 & 5.789907 & 5.853239 & 5.815505 \\
1 & -497.3794 & 219.4021 & 0.001548 & 4.880937 & $5.197597^{*}$ & $5.008924^{*}$ \\
2 & -478.518 & 36.1214 & $0.001507^{*}$ & 4.853943 & 5.423929 & 5.084318 \\
3 & -465.8648 & 23.75452 & 0.001556 & 4.885517 & 5.708831 & 5.218281 \\
4 & -455.84 & 18.44181 & 0.001648 & 4.941887 & 6.018528 & 5.37704 \\
5 & -438.663 & 30.95098 & 0.001632 & 4.930783 & 6.260751 & 5.468325 \\
6 & -414.0998 & $43.33332 *$ & 0.001508 & $4.849998^{*}$ & 6.433293 & 5.489929 \\
7 & -407.9924 & 10.54389 & 0.001659 & 4.943324 & 6.779947 & 5.685644 \\
8 & -402.5114 & 9.255651 & 0.001839 & 5.04256 & 7.13251 & 5.887269 \\
\hline
\end{tabular}

* lag order selected by the criterion. Sample: 2000M06 2018M11. Included observations: 212.

Table 7. Lag length criteria: GPR Israel, FXFXD, and FSI.

\begin{tabular}{ccccccc}
\hline Lag & LogL & LR & FPE & AIC & SC & HQ \\
\hline 0 & -608.7753 & NA & 0.064431 & 5.771465 & 5.818964 & 5.790663 \\
1 & -538.8341 & 137.2431 & 0.036259 & 5.196548 & $5.3865 *$ & $5.2733^{*}$ \\
2 & -528.0782 & 20.80142 & 0.035665 & 5.179983 & 5.512475 & 5.314369 \\
3 & -519.9289 & 15.52988 & 0.035958 & 5.188009 & 5.662997 & 5.379988 \\
4 & -511.4025 & 16.00705 & 0.036128 & 5.192477 & 5.809962 & 5.44205 \\
5 & -500.2686 & 20.58722 & 0.035422 & 5.172346 & 5.932327 & 5.479512 \\
6 & -483.1903 & $31.0955 *$ & $0.03284 *$ & $5.09613 *$ & 5.998613 & 5.460895 \\
7 & -479.173 & 7.200827 & 0.03445 & 5.143141 & 6.188116 & 5.565496 \\
8 & -476.0988 & 5.423197 & 0.03647 & 5.199046 & 6.386517 & 5.678994 \\
\hline
\end{tabular}

* lag order selected by the criterion. Sample: 2000M06 2018M11. Included observations: 212.

Table 8. Lag length criteria: GPR Saudi Arabia, FSI, and FXFXD.

\begin{tabular}{ccccccc}
\hline Lag & LogL & LR & FPE & AIC & SC & HQ \\
\hline 0 & -667.9574 & NA & 0.112608 & 6.329786 & 6.377285 & 6.348984 \\
1 & -611.1135 & 111.5428 & 0.071705 & 5.878429 & $6.06842 *$ & $5.95522^{*}$ \\
2 & -601.3129 & 18.95386 & 0.07117 & 5.870877 & 6.203369 & 6.005262 \\
3 & -593.6487 & 14.60535 & 0.072083 & 5.883479 & 6.358467 & 6.075458 \\
4 & -587.2287 & 12.05261 & 0.073877 & 5.907818 & 6.525304 & 6.157391 \\
5 & -579.4961 & 14.29804 & 0.074796 & 5.919775 & 6.679757 & 6.226942 \\
6 & -563.4063 & $29.2957 *$ & $0.06999 *$ & $5.85288 *$ & 6.755368 & 6.21765 \\
7 & -561.7665 & 2.939121 & 0.075091 & 5.922326 & 6.967301 & 6.34468 \\
8 & -559.1891 & 4.546896 & 0.079866 & 5.982916 & 7.170388 & 6.462865 \\
\hline
\end{tabular}

* lag order selected by the criterion. Sample: 2000M06 2018M11. Included observations: 212.

\subsection{Vector Autoregressive Model-VAR, Residual Serial Correlation, and Granger Causality Test}

The VAR model is conceived to capture dynamic interactions among the variables undertaken. The cause-and-effect relationship among variables can be verified under the Block Exogeneity Wald framework. For instance, if past values of one variable such as FSI helps predict future values of another variable such as ECO, then it is said that FSI Granger causes ECO or that ECO is affected by FSI. The simple Granger causality test considers only two variables, and it is expressed in the following way:

$$
\begin{gathered}
\mathrm{FSI}_{t}=\mathrm{a}_{1}+\sum_{i=1}^{m} \alpha i \mathrm{ECO}_{t-i}+\sum_{j=1}^{n} \beta \mathrm{i} \mathrm{FSI}_{t-j}+\varepsilon t \\
\mathrm{ECO}_{t}=\mathrm{a}_{2}+\sum_{i=1}^{p} \theta i \mathrm{FSI}_{\mathrm{t}-\mathrm{i}}+\sum_{j=1}^{q} \phi \mathrm{i} \mathrm{ECO}_{\mathrm{t}-\mathrm{j}}+z^{\prime} t
\end{gathered}
$$


where $\mathrm{ECO}_{t}$ and $\mathrm{FSI}_{t}$ are the growth rate of $\mathrm{ECO}$ and FSI in time $t, \mathrm{ECO}_{t-i}$ and $\mathrm{FSI}_{t-i}$ are the growth rate of ECO and FSI in time $t-i$, and $\varepsilon$ and 3 denote error terms. Based on both Ordinary Least Squares (OLS) coefficient and significance, possible cases obtained are:

Unidirectional Granger causality from FSI to ECO or from ECO to FSI means that one variable increases the prediction on the second variable but not vice versa.

Bidirectional causality is where ECO predicts FSI and FSI predicts ECO too.

Independence between ECO and FSI indicates absence of Granger causality.

Granger causality is often tested in a context of model. Since omitted variable bias might cause problems, this paper considers VAR models or $\mathrm{n}$ - equation VAR with nvariable linear system in which each variable is a linear function of its own lagged values and past values of the remaining $n-1$ variables (Stock and Watson 2001). A VAR model has at least three variables. Given $Y_{t}$, the vector of variables, the classical VAR model becomes:

$$
\mathrm{Y}_{t}=\sum_{j=1}^{p} \mathrm{AjY}_{t-j}+\mathrm{u}_{1}
$$

where $Y_{t}$ is an $\mathrm{m} \times 1$ vector of the endogenous variables and $\mathrm{u}_{t}$ is an $\mathrm{m} \times 1$ vector of the error terms in Equation (3).

$p$ is the number of lags that adequately models the dynamic structure. The coefficients of further lags of variables are not statistically significant, and the error terms are white noise. The error terms may, however, be correlated across equations. If the $p$ parameters are jointly significant, then the null hypothesis that states that one variable (x) does not Granger cause the other variable (y) can be rejected. Similarly, if the $p$ parameters are jointly significant, then the null hypothesis that states that one variable (y) does not Granger cause the other variable $(\mathrm{x})$ can be rejected.

In this study, the dynamic relation between FSI, FXFXD, and ECO is first verified. Then, the possible dynamic relation between regional geopolitical risks and the Lebanese financial market is tested so the VAR model considers four variables: Israel GPR, Saudi Arabia GPR, FSI, and FXFXD. Finally, the VAR is run twice, as a robustness check, by including each time one GPR (GPR of Israel or Saudi Arabia) and excluding the other one.

\subsubsection{Residual Serial Correlation}

The VAR residual serial correlation-Lagrange Multiplier (LM) tests are performed in Tables 9-11 to assess the validity of VAR regressions and to make sure the null hypothesis of the absence of autocorrelation in lag given by AIC at $5 \%$ is accepted.

Table 9. VAR residual serial correlation.

\begin{tabular}{|c|c|c|c|}
\hline \multicolumn{4}{|c|}{ FSI, FXFXD, ECO } \\
\hline \multicolumn{2}{|c|}{ Null Hypothesis: No Serial Correlation } & \multicolumn{2}{|c|}{ Null Hypothesis: No Serial Correlation } \\
\hline Lag $=2$ & Prob. & Lag 1 to 2 & Prob. \\
\hline 1 & 0.5921 & 1 & 0.5921 \\
\hline 2 & 0.0628 & 2 & 0.1607 \\
\hline
\end{tabular}

The null hypothesis of no residual autocorrelation is not rejected at conventional significance level.

Table 10. VAR residual serial correlation.

\begin{tabular}{|c|c|c|c|}
\hline \multicolumn{4}{|c|}{ GPR Israel, GPR Saudi Arabian FSI, FXFXD } \\
\hline \multicolumn{2}{|c|}{ Null Hypothesis: No Serial Correlation } & \multicolumn{2}{|c|}{ Null Hypothesis: No Serial Correlation } \\
\hline Lag $=6$ & Prob. & Lag 1 to 6 & Prob. \\
\hline 1 & 0.839 & 1 & 0.839 \\
\hline 2 & 0.7848 & 2 & 0.9196 \\
\hline 3 & 0.6154 & 3 & 0.7981 \\
\hline 4 & 0.3849 & 4 & 0.7647 \\
\hline 5 & 0.7907 & 5 & 0.8718 \\
\hline 6 & 0.0289 & 6 & 0.6758 \\
\hline
\end{tabular}

The null hypothesis of no residual autocorrelation is not rejected at conventional significance level. 
Table 11. VAR residual serial correlation with one GPR.

\begin{tabular}{|c|c|c|c|c|c|c|c|}
\hline \multicolumn{4}{|c|}{ A: GPR Israel, FSI, FXFXD } & \multicolumn{4}{|c|}{ B: GPR Saudi Arabia, FSI, FXFXD } \\
\hline \multicolumn{2}{|c|}{$\begin{array}{l}\text { Null Hypothesis: No } \\
\text { Serial Correlation }\end{array}$} & \multicolumn{2}{|c|}{$\begin{array}{l}\text { Null Hypothesis: No } \\
\text { Serial Correlation }\end{array}$} & \multicolumn{2}{|c|}{$\begin{array}{l}\text { Null Hypothesis: No } \\
\text { Serial Correlation }\end{array}$} & \multicolumn{2}{|c|}{$\begin{array}{l}\text { Null Hypothesis: No } \\
\text { Serial Correlation }\end{array}$} \\
\hline $\operatorname{Lag}=6$ & Prob. & Lag 1 to 6 & Prob. & $\operatorname{Lag}=6$ & Prob. & Lag 1 to 6 & Prob. \\
\hline 1 & 0.9619 & 1 & 0.9619 & 1 & 0.8927 & 1 & 0.8927 \\
\hline 2 & 0.8500 & 2 & 0.9772 & 2 & 0.8389 & 2 & 0.93 \\
\hline 3 & 0.5928 & 3 & 0.9163 & 3 & 0.5858 & 3 & 0.9065 \\
\hline 4 & 0.5456 & 4 & 0.9234 & 4 & 0.8565 & 4 & 0.9773 \\
\hline 5 & 0.9479 & 5 & 0.9863 & 5 & 0.961 & 5 & 0.9974 \\
\hline 6 & 0.5999 & 6 & 0.9823 & 6 & 0.607 & 6 & 0.9904 \\
\hline
\end{tabular}

The null hypothesis of no residual autocorrelation is not rejected at conventional significance level.

\subsubsection{Granger Causality Test}

Granger causality tests are run to examine the causal relation between regional GPRs and FSI along with FXFXD and ECO. The results are reported in Tables 12-14.

Table 12. Granger causality Tests: ECO, FSI, and FXFXD.

\begin{tabular}{ccc}
\hline \multicolumn{2}{c}{ ECO, FSI, and FXFXD } & \\
\hline $\begin{array}{c}\text { Number of Observations: 220. Lag 2 } \\
\text { Null Hypothesis: } \rightarrow \text { Indicates Does Not Granger Cause }\end{array}$ & F-Stat. & Prob. \\
\hline ECO $\rightarrow$ FSI & 0.28005 & 0.6420 \\
FSI $\rightarrow$ ECO & 5.18202 & 0.0046 \\
FXFXD $\rightarrow$ FSI & 2.30214 & 0.0863 \\
FSI $\rightarrow$ FXFXD & 2.43101 & 0.0819 \\
FXFX $\nrightarrow$ ECO & 1.21361 & 0.2358 \\
ECO $\rightarrow$ FXFXD & 0.49904 & 0.7304 \\
\hline
\end{tabular}

Table 13. Granger causality tests: GPR Israel, Saudi Arabia, FSI, and FXFXD.

\begin{tabular}{ccc}
\hline \multicolumn{2}{c}{ GPR Israel, Saudi Arabia, FSI, and FXFXD } & \\
\hline $\begin{array}{c}\text { Number of Observations: 214 Lag 6 } \\
\text { Null Hypothesis: } \nrightarrow \text { Indicates Does Not Granger Cause }\end{array}$ & F-Stat. & Prob. \\
\hline GPR Saudi Arabia $\nrightarrow$ FXFXD & 1.46796 & 0.1908 \\
FSI $\nrightarrow$ FXFXD & 3.40876 & 0.0073 \\
FXFXD $\nrightarrow$ FSI & 3.65865 & 0.0033 \\
GPR Saudi Arabia $\nrightarrow$ FSI & 0.93943 & 0.4678 \\
GPR Israel $\nrightarrow$ FSI & 2.00320 & 0.0669 \\
GPR Israel $\nrightarrow$ FXFXD & 1.12679 & 0.3480 \\
\hline
\end{tabular}

Table 14. Granger causality tests with one GPR.

\begin{tabular}{|c|c|c|c|c|c|}
\hline \multicolumn{3}{|c|}{ A: GPR Israel, FSI, and FXFXD } & \multicolumn{3}{|c|}{ B: GPR Saudi Arabia, FSI, and FXFXD } \\
\hline $\begin{array}{l}\text { Observations: } 214 \text {. Lag } 6 \\
\text { Null Hypothesis: } \nrightarrow \\
\text { Indicates Does Not } \\
\text { Granger Cause }\end{array}$ & F-Stat & Prob. & $\begin{array}{c}\text { Observations: } 214 \text {. Lag } 6 \\
\text { Null Hypothesis: } \nrightarrow \\
\text { Indicates Does Not } \\
\text { Granger Cause }\end{array}$ & F-Stat & Prob. \\
\hline GPR Israel $\nrightarrow$ FSI & 2.003 & 0.048 & GPR Saudi Arabia $\nrightarrow$ FXFXD & 1.197 & 0.496 \\
\hline GPR Israel $\nrightarrow$ FXFXD & 1.126 & 0.441 & FSI $\nrightarrow$ FXFXD & 3.4087 & 0.007 \\
\hline FXFXD $\nrightarrow$ FSI & 3.365 & 0.002 & FXFXD $\nrightarrow$ FSI & 3.6586 & 0.003 \\
\hline FSI $\nrightarrow$ FXFXD & 3.657 & 0.002 & GPR Saudi Arabia $\nrightarrow$ FSI & 0.814 & 0.464 \\
\hline
\end{tabular}

\subsection{Impulse-Response Functions and Variance Decompositions of Variables}

The Impulse-Response Functions (IRFs) aim to analyze the dynamic effects of the system when the model receives an impulse or an exogenous shock on the dynamic path 
of the variables of each estimated VAR. The departure point of every IRF for a linear VAR model is its moving average (MA) representation, which is also the Forecast Error Impulse Response (FEIR) function $\Phi_{i}$ for the $i$ th period after the shock is obtained by

$$
\Phi_{i}=\sum_{j=1}^{i} \Phi_{j=1} A_{j, i=1,2, \ldots}
$$

with $\Phi_{0}=I_{k}, K$ is the number of endogenous variables and $p$ is the lag order of the VAR.

The off-diagonal elements of the estimated variance-covariance matrix is not zero; therefore, a contemporaneous correlation between the variables in the VAR model would exist. In this study, the IRFs consider some restrictions on the VAR errors to address possible contemporaneous correlations that residual impulses ignore: the Cholesky decomposition method. The Cholesky decomposition method isolates the structural errors by recursive orthogonalization. Further information on contemporaneous relationships can be introduced to the FEIR by simply multiplying it by a matrix F:

$$
\Theta_{i}=\Phi_{i} \mathrm{~F} \text { for } i=0,1, \ldots
$$

The orthogonal impulse response functions consist of decomposing the variancecovariance matrix so that $\sum=\mathrm{PP}^{\prime}$, where $\mathrm{P}$ is a lower triangular matrix with positive diagonal elements, which is often obtained by a Cholesky decomposition. The latter requires placing variables of interest on the basis of the speed at which the variables act in response to shocks. Accordingly, the variables placed higher in the ordering have contemporaneous impact on the variables lower in the ordering. However, the variables placed lower in the ordering do not have a contemporaneous impact on the variables higher in the ordering.

The corresponding orthogonal impulse response function is then:

$$
\Theta_{i}^{0}=\Phi_{i} \mathrm{P}
$$

This study considers the GPR of Israel to have a greater impact; hence, it is first orderedorthogonalized in IRFs. The response of ECO to FSI and to other variables (combined) are reported in Figure 3. The combined response of FSI and FXFXD to GPR shocks are reported in Figure 4. The global multiple VAR model IRFs are reported in Figure A1.
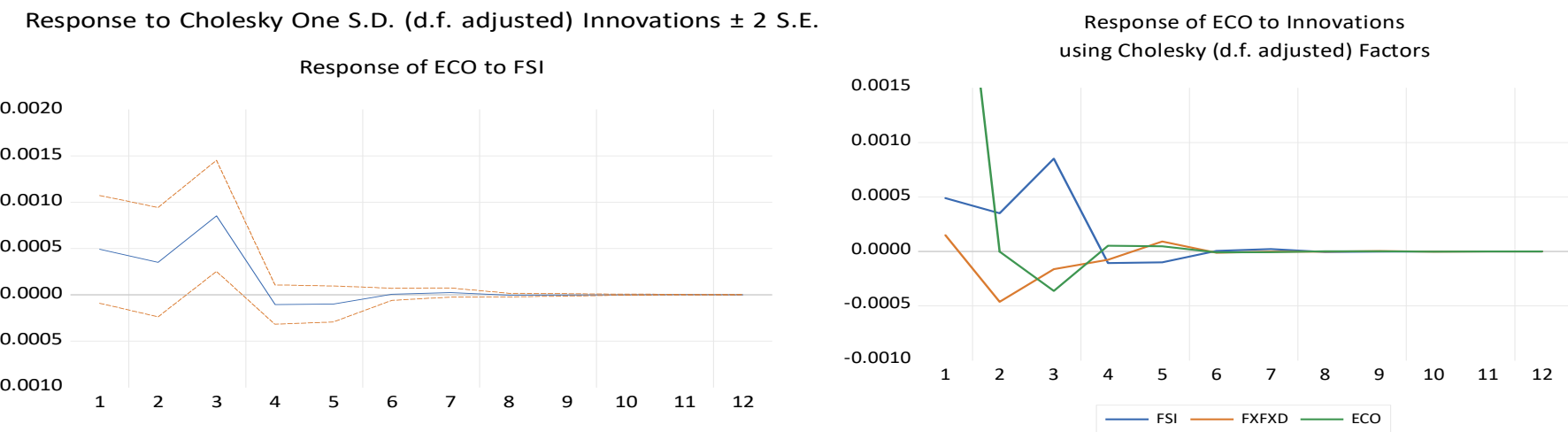

Figure 3. Response of output to FSI and FXFXD shocks. 


\section{Response to Cholesky One S.D. (d.f. adjusted) Innovations}

\section{Response of FSI to Innovations}

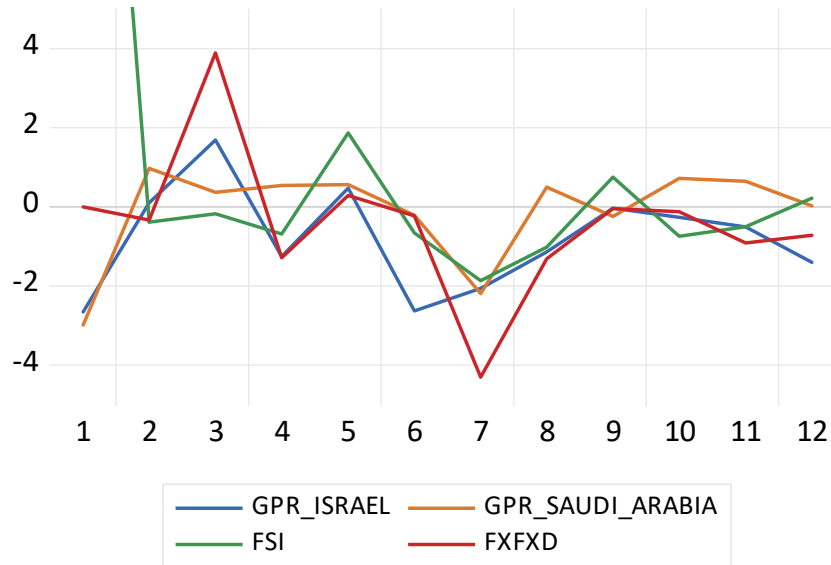

Response of FXFXD to Innovations

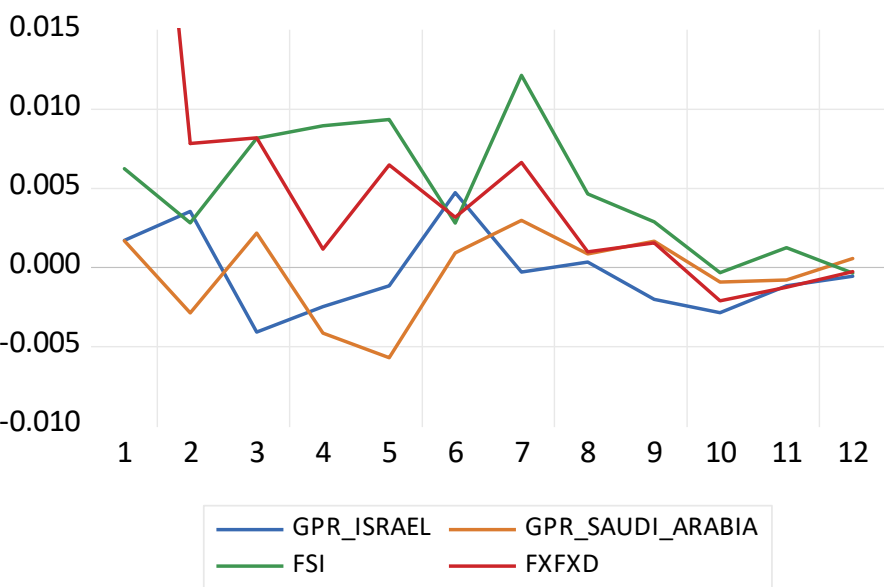

Figure 4. Combine impulse response functions of FSI and FXFXD to innovation.

Variance Decompositions of Variables

The variance decomposition of variables shows the portion of variance in the forecast error for each variable due to innovations to all variables in the system (or when a shock is given to one variable). Variance decompositions are represented graphically in Figure 5 and numerically in Table A1 in Appendix A.

Variance Decomposition using Cholesky (d.f. adjusted) Factors \pm 2 S.E.
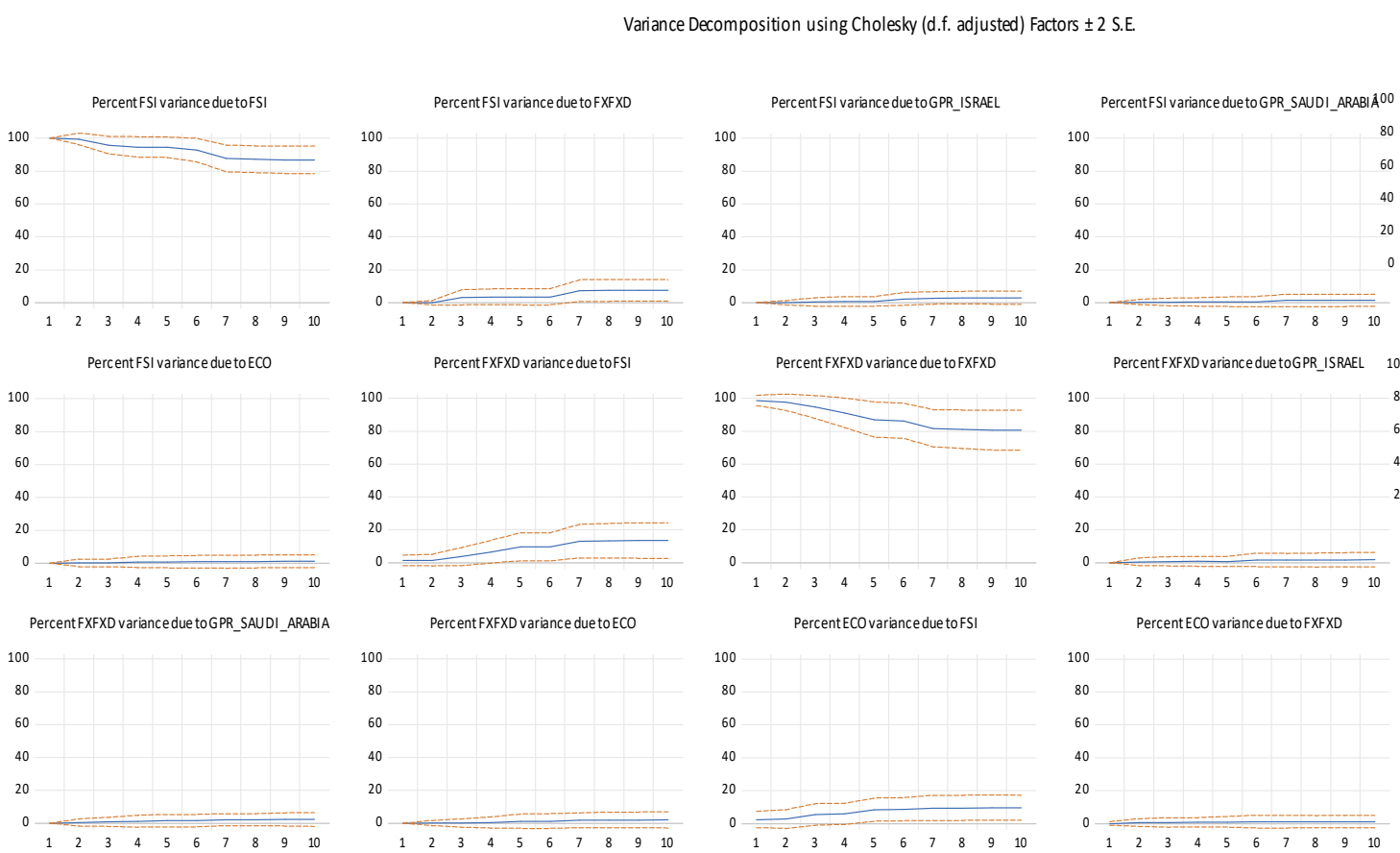

PercentECO variance due to ECO
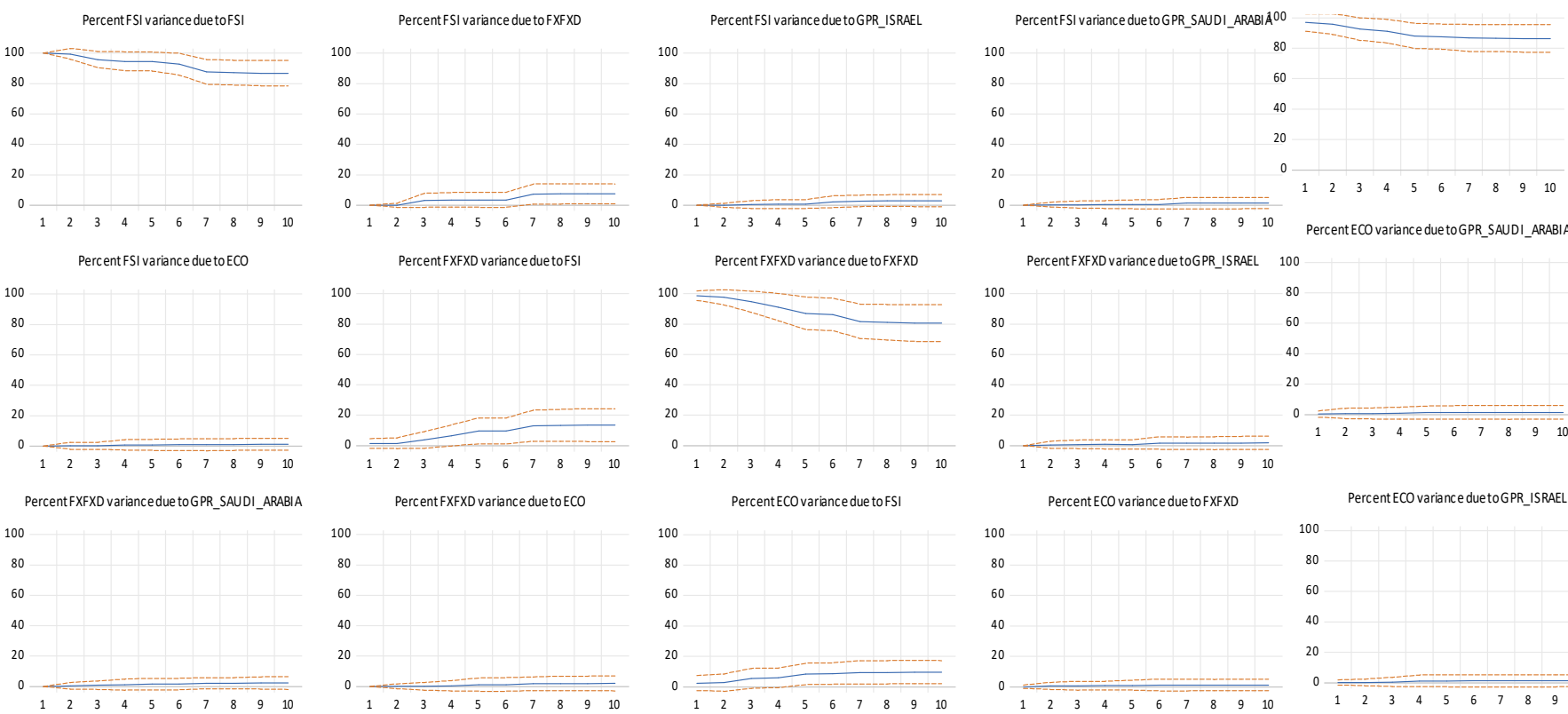

PercentECO variance due toGPR_SAUDI_ARABIA

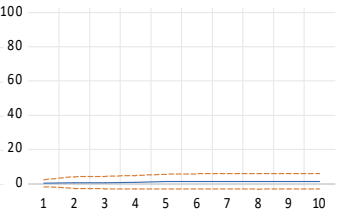

Figure 5. Variance decomposition of variables.

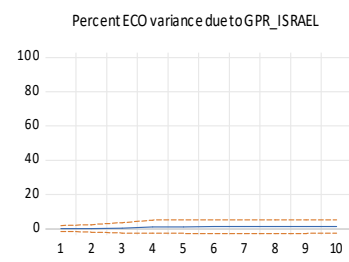

\section{Results and Discussion}

After verifying in Table 4 that all variables are stationary and after verifying in Tables 9-11 the absence of residual serial correlation in lag given by AIC, this section aims to interpret results obtained from running Granger causality tests under VAR models, impulse response functions, and variance decomposition of variables. 


\subsection{FSI and ECO Relation: FSI $\rightarrow E C O$}

Table 12 exhibits the results obtained from the multivariate Granger causality tests under VAR models between FSI, ECO, and FXDFX at lag 2 (Table 5). The results show a unidirectional causality from FSI to ECO significant at five percent. There is strong evidence that FSI helps predict output (proxied by employment in the private sector) within two months, while the opposite direction is not true since the $p$-value is 0.64 .

In other words, in Lebanon, a high a financial stress is powerful enough to Granger cause economic recession. The results are consistent with Illing and Liu (2003), and Cardarelli et al. (2009). Indeed, the financial market stability promotes economic growth through facilitating credit conditions, encouraging investments and purchases, as well as ensuring better expectations in the long term (Durusu-Ciftci et al. 2017; Cheng and Chiu 2018). Financial stability can even contribute to reducing poverty because changes in investments and economic activity growth (that are generated by financial stability) tend to increase more proportionally (Beck et al. 2007; Burgess and Pande 2005). A few studies found the causality from ECO to FSI to be significant. For instance, Kaminsky and Reinhart (2002), Mendoza and Terrones (2008), Calvo and Talvi (2005) and Reinhart and Rogoff (2009) found that a financial crisis is inevitable after a recession.

\subsection{FSI and FXFXD Bidirectional Causality: FXFXD $\leftrightarrow$ ↔ FSI $\rightarrow E C O$}

Table 12 also illustrates a bidirectional causality between the FX and the FSI at lag 2, which means that the FSI can predict future FXFXD shock and vice versa within two months. It sounds logical that FXFXD shocks cause FSI. In fact, FX are vital in a dollarized country; they guarantee a better exchange rate stability (Calvo 2006). They are considered auto-insurance against future financial crises (Calvo and Reinhart 2000). This explains the "psychological impact" behavior of post-crisis emerging countries holding excessively "too much of good thing" (Jeanne 2007; Obstfeld et al. 2009).

The FXFXD-FSI bidirectional causality is highly significant when the VAR model includes GPRs (with $p$-value $=0.00$ in Tables 13 and 14) and barely significant internally ( $p$-value $=0.08$ in Table 12), which indicates that, when uncertainty in the financial market (FSI) occurs (especially that resulting from geopolitical tensions), economic agents look after converting local currency to foreign ones (FXFXD). Consequently, FX depletion arises and then causes a more severe financial crisis (FSI) that ends up with an economic contraction (as verified previously that FSI causes ECO. The deduction seems consistent with the IMF country report for Lebanon by Ahuja et al. (2017) who stated that " $A$ common shock to bank liquidity, that leads to a demand for foreign currency, could result in a drop in international reserves (1 percent of deposits are equivalent to 3.7 percent of reserves)".

\subsection{Israel GPR, Saudi Arabia GPR, FSI, and FXFXD Causality: Israel GPR $\rightarrow F S I$}

Table 13 reports the Granger causality relation between Israel, Saudi Arabia GPRs, FSI, and FXFXD at lag 6. (Table 14A verifies the dynamic relation by excluding from the VAR model the GPR of Saudi Arabia.) The results reveal a unidirectional causality from Israel GPR to FSI (the $p$-value is 0.066 in Table 13, and the $p$-value is 0.04 in Table 14A). Accordingly, Israel GPR seems to Granger cause a future financial crisis in Lebanon within six months. Similarly, the results in Tables 13 and 14 exhibit strong evidence that FSI helps predict FXFXD $(p$-value $=0.00)$ and overwhelming evidence that FXFXD helps predict FSI $(p$-value $=0.00)$. The bidirectional relation between FSI and FXFXD is aligned with previous results.

The Israel GPR starts Granger causing FSI who triggers FXFXD, which in return FXFXD leads to a deeper financial crisis (FSI) and ends with economic contraction. The findings seem consistent with previous deductions derived from the graphical analysis.

- $\quad$ Remark and further analysis

It should be noted that the results indicate that Israel and Hezbollah's threats can trigger a financial crisis in Lebanon. However, the results do not specify whether threats are generated from Israel or from Hezbollah, unless a Hezbollah GPR index is constructed. Regardless, a titfor-tat between Israel and Hezbollah (in Lebanon) exists; geopolitics is not necessarily expressed 
by military or terrorist attacks but through several media channels: never underestimate the power of words in hate radio speeches that mobilized people to commit genocide in Rwanda.

The social media platforms are indeed an important army channel for Hezbollah to raise risks or to prevent Israel from achieving its goal (Kalb and Saivetz 2007). Hezbollah's speeches and video messages have been extensively analyzed and interpreted in the literature.

Hezbollah seems to take advantage of the Israeli financial market (Tel Aviv stock market) sensitiveness to geopolitical risk-terrorist-suicide attacks (Eldor and Melnick 2004 ) in order to develop its geopolitical skills through media coverage. Accordingly, Jetter (2017), who analyzed the causality-relation between terrorist attacks and media coverage, mainly in The New York Times, concluded that Israel as well as Iraq and Colombia are more likely to respond to news than other countries.

Interestingly, Yarchi (2016) considered it strategic for Israel to be relatively weaker than Hezbollah in spreading geopolitical risks through media platforms. In fact, a wider broadcast of Israeli military attacks would increase the visibility of killed Palestinian civilians, which would trigger a widespread movement of sympathy and would raise the international voices demanding to stop Israeli attacks. Likewise, Israeli attacks on Palestinians tend to be committed when voters of the US are preoccupied by events (Durante and Zhuravskaya 2015).

On the other hand, social media and campaigns are not only limited to broadcasting Hezbollah's resistant military attacks but also to spreading its ideology and civilization considered as complementary to geopolitics (Kuçi 2020). Hezbollah employs all media platforms (through their own TV channels, radios, and websites) to promote its militia wing and to create a distinguished "brand image of terrorism" (Matusitz 2018). Hezbollah (resistance ideology) leaders' speeches and videos are translated in many languages and accessible all over the world, aiming to reach a wider audience. Many of them are perceived as being a resistance ideology "show-off" rather than triggering geopolitical risks to please its supporters and grow popularity (El Houri and Saber 2010). Moreover, they strive to educate their audience in several fields such as history, culture, music (religion and resistant songs), politics, religion, and beliefs as they are perceived by Hezbollah, the Iran's proxy (Weimann 2008). Likewise, Nilsson (2020) conducted a qualitative frame analysis of Hezbollah's speeches and found that they follow a diversity strategy. They are framed differently depending on the target: diversity of resistance, normalization of resistance, and social dimensions of resistance. In short, while both Israel and Hezbollah's military wings play geopolitics, Lebanese bears economic consequences.

\subsection{Saudi Arabia GPR, FSI and FXFXD: Saudi Arabia GPR $\rightarrow$ FSI and Saudi Arabia GPR $\rightarrow$ FXFXD}

Surprisingly, Tables 13 and 14B indicate that none of Saudi Arabia GPR's coefficients are significant $(p$-value $>0.1)$. Saudi Arabia seems to predict neither directly a financial crisis nor indirectly the FXFXD shocks. Saudi Arabia's geopolitical threats toward Hezbollah (in Lebanon) are not powerful enough to destabilize the Lebanese financial market as it does with Turkey. For instance, Mansour-Ichrakieh and Zeaiter (2019) proceeded with a similar empirical analysis between Saudi Arabia GPR and the Turkish financial market, concluded that the Saudi Arabian GPR can trigger severe financial crisis in Turkey and can even change its state (threshold) from a low stress level to a high stress level.

The findings raise the question on whether Saudi Arabia considers Turkey a nation competing at the ideology, economic, and military levels (Grumet 2015; Janine 2018) as more dangerous than Hezbollah.

- Remark and further analysis

In 2012, Saudi Arabia (followed by other gulf countries) announced a cold war against Hezbollah's terrorist attacks and military intervention in Syria. The cold war is expected to negatively affect the Lebanese economy through the touristic sector. It was verified by Hamadeh and Bassil (2017) that geopolitical risks, and more precisely terrorist attacks in Lebanon, have a greater negative impact on Arab tourists than on European ones. 
On the one hand, 40 percent of the total Lebanese migration are expatriate labor in Arab countries and around 20 percent of total Lebanese migration or 160,000 are employed in Saudi Arabia (De-Bel-Air 2017). They send remittances equivalent to about 5 billion dollars per year (about 11 percent of GDP). Consequently, the Gulf remittances' losses can reduce GDP and increase the unemployment rate to about seven percent (Ghaddar 2017).

On the other hand, (Ghaddar 2017) reveals that Saudi Arabia contributes to about 25 percent of all visitor tourists. When Saudi Arabia decided to boycott Lebanon at economic and touristic levels, the tourism loss hurts the hotel sector, driving down occupancy to about 40 percent and the overnight hotel rates down to 56.6 percent. Likewise, the cold war drives up the unemployment rate, especially in the hospitality sector.

The Lebanese financial market appears to be intact although Saudi Arabia is heavily involved in the Lebanese touristic sector. In fact, the unidirectional causality between FSI and ECO shows that, in order to cause an economic recession, Saudi Arabia GPR must first trigger the Lebanese financial market (ECO does not Granger cause FSI).

\subsection{Impulse Response Functions and Variance Decomposition}

The VAR impulse response functions (IRFs) reflect the direction and the magnitude of the linkages between variables along the next twelve months. Figure 3 exposes the Cholesky IRFs of FXFXD and ECO to one standard deviation shocks of FSI on the adjustment path of the variables (FSI is first-order orthogonalized using Cholesky decomposition). Similarly, FSI and FXFXD responsiveness to one standard deviation shocks of GPRs are presented in Figure 4. Recall that the ECO and FXFXD signs are inverted, so positive fluctuations indicate economic recession and FX depletion. Multiple IRFs represented in Figure A1 show that the variables are in the 95 percent confidence interval.

Figure 3 shows a slight decrease in output during the first two months followed by a shock increase between period 2 and period 4 . The shock decline of output starts after four months and then converges to the zero level eight months after the FSI shock.

Figure 4 shows an asymmetric shock amplitude between FSI and FXFXD despite their bidirectional Granger causality. Indeed, the FSI's response to one standard deviation shock of FXFXD is obvious and reaches 3 between periods 3 and 4 while the opposite case (FXFXD response to FSI shock) has about a ten times smoother effect. Interestingly, FSI turns negative after the first two months and then jumps. In fact, FSI shock is somehow absorbed for the firsts few months by depleting gradually central bank's FX before having recourse to financial operations that aim to borrow foreign currencies. Both FSI and FXFXD responsiveness last around eight to ten months.

Similarly, FSI responsiveness to Israel GPR shock is obviously observed. It lasts more than six months. FSI shock needs about ten to eleven months to converge to the zero level.

The variance decomposition of endogenous variables is represented graphically in Figure 5 and reported numerically in Tables A1 and A2. They examine how important each of the shocks are as components of the overall (unpredictable) variance of each of the variables over time. Shock to ECO accounts for about $93 \%$ of the fluctuation in ECO, which reveals an own shock. FSI accounts for 2 percent of ECO fluctuation in the first two months and reaches 5.5 percent in the next months. The variance decompositions of FSI show that more than 92 percent of FSI shocks are explained by FSI itself in the first 2 months. Other variables such as Israel GPR and FXFXD become gradually more influenced starting at times 4 and 5. They contribute to about 5 to 7 percent of FSI fluctuation. Similarly, in the first two months, FXFXD reflects own shock since it accounts for more than 95 percent of its fluctuation. However, with time, FSI contribution to FXFXD fluctuation increases gradually to 14 percent one year after the initial impulse while own shock contribution drops to 81 percent.

\section{Conclusions}

Over the years, Hezbollah's role evolved from being hosted by Lebanon to taking Lebanon hostage (Schmitt 2007) at the behest of the Iran's ideology (DeVore 2012; Seliktar and Rezaei 2020). Hezbollah's activities that are mostly illegal have harmful consequences 
on the Lebanese economy. Moreover, it takes sovereign decisions as well as risky actions in the region, mainly against Israel (for resistance ideology raison d'être) and Saudi Arabia (for ideological and geopolitical rivalry), and then forces Lebanon to pay the consequences (Grumet 2015). Geopolitical consequences of Hezbollah's domination have been extensively studied and analyzed in politics, sociology, and geopolitics. However, empirical economic studies remain rare, if not inexistent. They are rather descriptive and informative economic news, published in newspapers and press releases. Economic reports elaborated by the United Nations, Reuters, the World Bank, or other international organizations are limited to estimating the cost of reconstruction (after a war) or to exposing in value the costs or the losses on welfare, agriculture, and employment.

The present paper aims to analyze empirically the impact of regional geopolitical tensions with Hezbollah on the Lebanese financial market and economic activity (ECO).

It first proceeds with graphical analysis of the Lebanese financial market that is measured with the Financial Stress Index (FSI), on a monthly basis from 1998 to January 2018 (Ishrakieh et al. 2020a, 2020b). In this study, the FSI was updated to November 2018 and its analysis started from June 2006 after complete Israeli deliberation from Lebanese territories. Graphical analysis presumes that local economic and political trouble, although numerous, do not seem to generate high FSI spikes whereas high FSI spikes seem to be associated with regional geopolitical tensions where Hezbollah is in the details. Similarly, it appears that most of the recession periods overlap positive, high FSI spikes. Nevertheless, empirical tests are crucial to verify the preliminary deductions.

Then, based on Granger causality tests under VAR models followed by the Cholesky impulse-response functions and variance decomposition of variables, this paper examines the dynamic relation and interaction between Israeli and Saudi Arabian geopolitical risks (toward Hezbollah), with the Lebanese financial market and economic activity. The financial stress index is the most common variable used in the literature to test under VAR models its dynamic relationship with the economic activity (Calvo and Talvi 2005; Claessens et al. 2010; Reinhart and Rogoff 2009; Davig and Hakkio 2010; Cevik et al. 2016) or with geopolitical risks along with other economic variables (Çamlıca 2016; Das et al. 2019; Mansour-Ichrakieh and Zeaiter 2019; Saint Akadiri et al. 2020).

The GPR index of Saudi Arabia and Israel were taken from Caldara and Iacoviello (2018), calculated on a monthly basis from January 1985 to September 2018 (GPR data were lately updated to October 2020).

The innovative character of this paper is also in the choice of the adequate level of foreign reserves (FX) that best fits a dollarized country (Gonçalves 2008): The central bank's foreign reserves to total deposit in foreign currencies (denoted FXFXD).

This study aimed to achieve to one of two possible conclusions:

If the Lebanese financial market shows independency or low dependency-causality to the regional geopolitical risks, then Hezbollah geopolitical tensions with Israel and Saudi Arabia do not seem to negatively affect the Lebanese financial stability. In consequence, economic reforms, monetary and fiscal policies can be improved independently from the geopolitical, international, and diplomatic arrangements.

If the Lebanese financial market shows significant dependency-causality to the regional geopolitical risks, then Hezbollah's tensions with Israel and Saudi Arabia trigger Lebanese financial stability and economic activity. Therefore, instead of solving the economic crisis from a purely economic perspective, measures towards negotiation and conflict resolution with the neighborhood are needed, which require de-Hezbollizing Lebanon.

The results reveal a significant unidirectional relation from FSI to ECO ( $p$-value 0.004), which means that, in Lebanon, a financial stress seems to be followed by an economic recession within two months while the economic activity does not seem to be strong enough to "Granger cause" a financial market instability.

Empirical outcomes also expose a bidirectional relation between FXFXD and FSI that is highly significant when the VAR model includes GPRs (with $p$-value $=0.00$ ) and barely significant internally $(p$-value $=0.08)$. The FXFXD-FSI bidirectional relationship indicates 
that, when uncertainty (especially resulting from geopolitical tensions) is expressed in the financial market (FSI), economic agents look after converting local currency to foreign ones (FXFXD). Consequently, the depletion of FX arises and then "Granger causes" a more severe financial crisis (FSI) that may ends in an economic contraction (as verified by the unidirectional relation from FSI and ECO). The deduction seems aligned with the IMF-2017 country report analysis for Lebanon where Ahuja et al. (2017) stated: "A common shock to bank liquidity, that leads to a demand for foreign currency, could result in a drop in international reserves (1 percent of deposits are equivalent to 3.7 percent of reserves)".

The findings indicate that Israel and Saudi Arabia geopolitical risks affect the Lebanese financial market differently. While Israel geopolitical risks appear to be a good predictor for the Lebanese financial crisis within six months, Saudi Arabia GPR does not. This means that the Lebanese financial market remains intact although its heavy involvement in the Lebanese economy that is mainly conducted through the labor market and the touristic sector. In fact, based on the FSI and ECO unidirectional causality, the Lebanese financial market must first be affected in order to hit the economic activity. In other words, even if the GRP of Saudi Arabia triggers the Lebanese economy, the financial market will not be affected. Undoubtedly, a more pointed dynamic relation between Saudi Arabia GPR and the Lebanese economic sectors or, more precisely, the touristic sector will be more informative. Likewise, Hamadeh and Bassil (2017) verified the impact of geopolitics, or more precisely terrorism, on the Lebanese touristic sector. Moreover, they found that Arab tourists are significantly more affected than the European ones.

Although Saudi Arabia's geopolitical risks toward Hezbollah (in Lebanon) are not powerful enough to destabilize the Lebanese financial market, it is found to be a threat for Turkey. Mansour-Ichrakieh and Zeaiter (2019) proceeded with a similar empirical analysis between Saudi Arabia GPR and the Turkish financial market and found that Saudi Arabia GPR does not only trigger a severe financial crisis in Turkey, but it also changes its state (threshold VAR) from a low stress level to a high stress level. The findings raise the question of whether Saudi Arabia considers Turkey more dangerous than Hezbollah.

Finally, this study exhibits the existence of a unidirectional causality between Israel GPR and the Lebanese financial market and sheds light on its deleterious effect. In fact, based on the previous bidirectional causality between FSI and FXFXD and the dynamic relation between FSI and ECO, this paper concludes that, when Israel and Hezbollah play geopolitics, the Lebanese financial market seems to respond obviously, by gradually depleting the central bank's foreign reserves. The latter in return predicts further destabilization of the Lebanese financial market before hitting the economic activity.

The findings do not specify whether the threats are generated from Israel or from Hezbollah unless a Hezbollah GPR index is constructed and then VAR models and Granger causality tests are run.

Regardless of who acts and who reacts (Hezbollah or Israel), the perpetual tit-for-tat between them drives Lebanon and its economy the main victims. For instance, in July 2006, after Hezbollah captured Israeli soldiers, Israel responded severely and attacked Hezbollah inside of Lebanon (Sharp et al. 2006). Although "Israel did not attack the government of Lebanon, but rather Hizbullah military assets within Lebanon" (Schmitt 2007), Lebanon's cities and infrastructures underwent destruction as well as more than 900,000 Lebanese civilians or about $\frac{1}{4}$ of the total population became displaced (Internal Displacement Monitoring Center 2010).

Geopolitical tension is not necessarily expressed by military or terrorist attacks, but it is also through several media channels. Media campaigns raise geopolitical risks especially when the speakers are engaged in military or terrorist acts and want visibility in the media following their actions (Tsesis 2017). Hezbollah's leader is so talented in public speaking that his speeches are extensively studied in the literature. Many researchers have been breaking down, analyzing, interpreting, and even revealing hidden messages.

Israel geopolitical risks overshoot the Lebanese financial instability through depleting central bank's foreign reserves and then end up weakening the economic activity. 
Since Israeli geopolitical risks cause deleterious effect on the Lebanese financial stability, the author concludes that, in order to enhance a future financial stability and to promote economic growth, political-geopolitical measures toward negotiation and conflict resolution with the neighborhood (against Hezbollah ideology) are needed, which require first de-Hezbollizing Lebanon. Future studies in law, political science, and geopolitics are expected in order to verify how "realistic" is it to "de-Hezbollize" Lebanon.

Funding: This research received no external funding.

Acknowledgments: I (Layal Mansour-Ichrakieh) am grateful for the helpful comments of participants during the presentation of my preliminary findings, on 30 June and 1 July 2019, at the Western Economic Association International, in San Francisco, USA. I am thankful to Hiba Naccache from the Lebanese American University, who has verified my models and my results. I am grateful to Samar Hamieh, from the Lebanese University and Beirut Arab University for the English editing.

Conflicts of Interest: The author declares no conflict of interest.

\section{Appendix A}
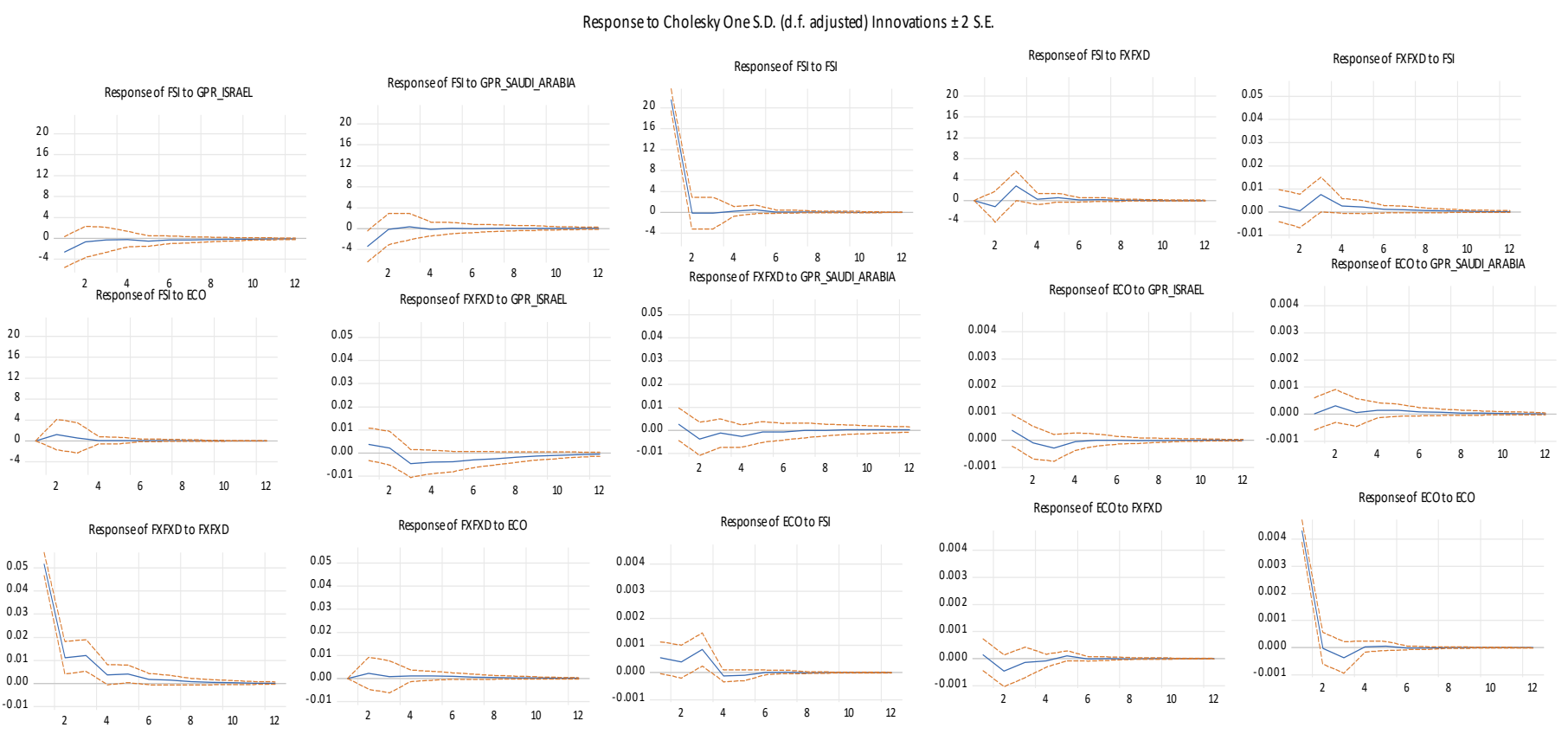

Figure A1. Impulse response functions.

\section{Appendix B}

Table A1. Variance decompositions of ECO.

\begin{tabular}{ccccc}
\hline TIME & S.E. & FSI & FXFXD & ECO \\
\hline 1 & 0.0043 & 1.2825 & 0.1173 & 98.6003 \\
2 & 0.0044 & 1.9049 & 1.2337 & 96.8615 \\
3 & 0.0045 & 5.4552 & 1.3114 & 93.2334 \\
4 & 0.0045 & 5.5062 & 1.3395 & 93.1543 \\
5 & 0.0045 & 5.5505 & 1.3795 & 93.0700 \\
6 & 0.0045 & 5.5506 & 1.3802 & 93.0692 \\
7 & 0.0045 & 5.5531 & 1.3801 & 93.0668 \\
8. & 0.0045 & 5.5531 & 1.3802 & 93.0667 \\
9 & 0.0045 & 5.5531 & 1.3802 & 93.0667 \\
10 & 0.0045 & 5.5531 & 1.3802 & 93.0666 \\
\hline
\end{tabular}

Cholesky ordering: FSI, FXFXD, ECO. 
Table A2. Variance decomposition of FSI and FXFXD.

\begin{tabular}{|c|c|c|c|c|c|c|c|c|c|c|c|}
\hline \multicolumn{6}{|c|}{ Variance Decomposition of FSI: } & \multicolumn{6}{|c|}{ Variance Decomposition of FXFXD: } \\
\hline Period & S.E. & $\begin{array}{c}\text { GPR } \\
\text { Israel }\end{array}$ & $\begin{array}{c}\text { GPR } \\
\text { Saudi } \\
\text { Arabia }\end{array}$ & FSI & FXFXD & Period & S.E. & $\begin{array}{c}\text { GPR } \\
\text { Israel }\end{array}$ & $\begin{array}{c}\text { GPR } \\
\text { Saudi } \\
\text { Arabia }\end{array}$ & FSI & FXFXD \\
\hline 1 & 0.15 & 1.54 & 1.96 & 96.50 & 0.00 & 1 & 0.22 & 0.12 & 0.11 & 1.54 & 98.23 \\
\hline 2 & 0.17 & 1.54 & 2.16 & 96.27 & 0.02 & 2 & 0.24 & 0.59 & 0.42 & 1.80 & 97.19 \\
\hline 3 & 0.17 & 2.09 & 2.10 & 92.60 & 3.21 & 3 & 0.25 & 1.16 & 0.57 & 4.11 & 94.16 \\
\hline 4 & 0.18 & 2.40 & 2.15 & 91.92 & 3.53 & 4 & 0.26 & 1.33 & 1.14 & 6.75 & 90.77 \\
\hline 5 & 0.18 & 2.42 & 2.20 & 91.86 & 3.52 & 5 & 0.26 & 1.31 & 2.15 & 9.28 & 87.27 \\
\hline 6 & 0.18 & 3.80 & 2.17 & 90.55 & 3.48 & 6 & 0.26 & 2.02 & 2.15 & 9.41 & 86.43 \\
\hline 7 & 0.19 & 4.38 & 2.96 & 85.84 & 6.82 & 7 & 0.27 & 1.89 & 2.29 & 13.33 & 82.49 \\
\hline 8 & 0.20 & 4.60 & 2.99 & 85.33 & 7.09 & 8 & 0.28 & 1.89 & 2.29 & 13.89 & 81.93 \\
\hline 9 & 0.20 & 4.59 & 3.00 & 85.33 & 7.08 & 9 & 0.28 & 2.00 & 2.36 & 14.07 & 81.57 \\
\hline 10 & 0.20 & 4.59 & 3.09 & 85.25 & 7.07 & 10 & 0.28 & 2.23 & 2.38 & 14.02 & 81.37 \\
\hline 11 & 0.20 & 4.63 & 3.16 & 85.02 & 7.20 & 11 & 0.28 & 2.27 & 2.39 & 14.05 & 81.29 \\
\hline 12 & 0.20 & 4.98 & 3.14 & 84.62 & 7.26 & 12 & 0.29 & 2.28 & 2.40 & 14.05 & 81.27 \\
\hline
\end{tabular}

\section{References}

Ahuja, Ashvin, Murtaza Syed, and Kevin Wiseman. 2017. Assessing Country Risk-Selected Approaches-Reference Note. Technical Notes and Manuals 17: 2017. [CrossRef]

Al-Aloosy, Massaab. 2020. Obliteration and Liberation Change to Deterrence: Hezbollah's Ideological Transformation Toward Israel and the Palestine Cause. In The Changing Ideology of Hezbollah. Cham: Springer, pp. 103-39.

Al-Yahyaee, Hamed Khamis, Mobeen Ur Rehman, Walid Mensi, and Idries Mohammad Wanas Al-Jarrah. 2019. Can uncertainty indices predict Bitcoin prices? A revisited analysis using partial and multivariate wavelet approaches. The North American Journal of Economics and Finance 49: 47-56. [CrossRef]

Apergis, Nicholas, Matteo Bonato, Rangan Gupta, and Clement Kyei. 2018. Does geopolitical risks predict stock returns and volatility of leading defense companies? Evidence from a nonparametric approach. Defence and Peace Economics 29: 684-96. [CrossRef]

Aysan, Ahmet Faruk, Ender Demir, Giray Gozgor, and Chi Keung Marco Lau. 2019. Effects of the geopolitical risks on Bitcoin returns and volatility. Research in International Business and Finance 47: 511-18. [CrossRef]

Badran, Tony, and Emanuele Ottolenghi. 2020. Hezbollah Finance in Lebanon: A Primary-Source Review. Available online: https: //www.fdd.org/analysis/2020/09/23/hezbollah-finance-in-lebanon/ (accessed on 23 September 2020).

Baker, Scott R., Nicholas Bloom, and Steven J. Davis. 2016. Measuring economic policy uncertainty. The Quarterly Journal of Economics 131: 1593-636. [CrossRef]

Balakrishnan, Ravi, Stephan Danninger, Selim Elekdag, and Irina Tytell. 2011. The transmission of financial stress from advanced to emerging economies. Emerging Markets Finance and Trade 47: 40-48. [CrossRef]

Beck, Thorsten, Asli Demirgüç-Kunt, and Ross Levine. 2007. Finance, inequality and the poor. Journal of economic growth 12: 27-49. [CrossRef]

Blom-Bank. 2017. Annual Report Lebanon. Beirut: Blom Bank (Research Department), Available online: https://www.blombank.com/ Library / Files / BLOM\%20BANK\%20Annual-Report-Lebanon-2017.pdf (accessed on 23 September 2020).

Bouoiyour, Jamal, Refk Selmi, Shawkat Hammoudeh, and Mark E. Wohar. 2019. What are the categories of geopolitical risks that could drive oil prices higher? Acts or threats? Energy Economics 84: 104523. [CrossRef]

Bouras, Christos, Christina Christou, Rangan Gupta, and Tahir Suleman. 2019. Geopolitical risks, returns, and volatility in emerging stock markets: evidence from a panel GARCH model. Emerging Markets Finance and Trade 55: 1841-56. [CrossRef]

Bry, Gerhard, and Charlotte Boschan. 1971. Front matter to Cyclical Analysis of Time Series: Selected Procedures and Computer Programs. In Cyclical Analysis of Time Series: Selected Procedures and Computer Programs. Cambridge: NBEr.

Burgess, Robin, and Rohini Pande. 2005. Do rural banks matter? Evidence from the Indian social banking experiment. American Economic Review 95: 780-95. [CrossRef]

Caldara, Dario, and Matteo Iacoviello. 2018. Measuring geopolitical risk. FRB International Finance Discussion Paper, 1222. [CrossRef]

Calvo, Guillermo A. 2006. Monetary Policy Challenges in Emerging Markets: Sudden Stop, Liability Dollarization, and Lender of Last Resort. Cambridge: National Bureau of Economic Research.

Calvo, Guillermo A., Alejandro Izquierdo, and Luis-Fernando Mejía. 2008. Systemic Sudden Stops: The Relevance of Balance-Sheet Effects and Financial Integration. Cambridge: National Bureau of Economic Research.

Calvo, Guillermo A., and Carmen M. Reinhart. 2000. Fixing for Your Life. Cambridge: National Bureau of Economic Research.

Calvo, Guillermo A., and Ernesto Talvi. 2005. Sudden Stop, Financial Factors and Economic Collpase in Latin America: Learning from Argentina and Chile. Cambridge: National Bureau of Economic Research.

Çamlıca, Ferhat. 2016. Responsiveness of monetary policy to financial stress in Turkey. Central Bank Review 16: 143-50. [CrossRef] 
Cardarelli, Roberto, Selim Ali Elekdag, and Subir Lall. 2009. Financial stress, downturns, and recoveries. IMF Working Papers 09/100: $1-58$.

Cepni, Oguzhan, David Gabauer, Rangan Gupta, and Khuliso Ramabulana. 2020. Time-Varying Spillover of US Trade War on the Growth of Emerging Economies. Pretoria: University of Pretoria.

Cevik, Emrah I., Sel Dibooglu, and Turalay Kenc. 2016. Financial stress and economic activity in some emerging Asian economies. Research in International Business and Finance 36: 127-39. [CrossRef]

Chadefaux, Thomas. 2014. Early warning signals for war in the news. Journal of Peace Research 51: 5-18. [CrossRef]

Cheng, Chak Hung Jack, and Ching-Wai Jeremy Chiu. 2018. How important are global geopolitical risks to emerging countries? International Economics 156: 305-25. [CrossRef]

Claessens, Stijn, Giovanni Dell'Ariccia, Deniz Igan, and Luc Laeven. 2010. Cross-country experiences and policy implications from the global financial crisis. Economic Policy 25: 267-93. [CrossRef]

Cunado, Juncal, Rangan Gupta, Chi Keung Marco Lau, and Xin Sheng. 2020. Time-varying impact of geopolitical risks on oil prices. Defence and Peace Economics 31: 692-706. [CrossRef]

Das, Debojyoti, M. Kannadhasan, and Malay Bhattacharyya. 2019. Do the emerging stock markets react to international economic policy uncertainty, geopolitical risk and financial stress alike? The North American Journal of Economics and Finance 48: 1-19. [CrossRef]

Davig, Troy, and Craig Hakkio. 2010. What is the effect of financial stress on economic activity. Federal Reserve Bank of Kansas City, Economic Review 95: 35-62.

De-Bel-Air, Françoise. 2017. Migration Profile: Lebanon. Migration Policy Center. [CrossRef]

Demetriades, Panicos O., Peter L. Rousseau, and Johan Rewilak. 2017. Finance, Growth and Fragility. Leicester: Division of Economics, School of Business, University of Leicester.

DeVore, Marc R. 2012. Exploring the iran-hezbollah relationship: A case study of how state sponsorship affects terrorist group decision-making. Perspectives on Terrorism 6: 85-107.

Durante, Ruben, and Ekaterina V. Zhuravskaya. 2015. Attack When the World Is Not Watching?: International Media and the Israelipalestinian Conflict. London: Centre for Economic Policy Research.

Durdu, Ceyhun Bora, Enrique G. Mendoza, and Marco E. Terrones. 2009. Precautionary demand for foreign assets in Sudden Stop economies: An assessment of the New Mercantilism. Journal of development Economics 89: 194-209. [CrossRef]

Durusu-Ciftci, Dilek, M. Serdar Ispir, and Hakan Yetkiner. 2017. Financial development and economic growth: Some theory and more evidence. Journal of Policy Modeling 39: 290-306. [CrossRef]

Eckstein, Zvi, and Daniel Tsiddon. 2004. Macroeconomic consequences of terror: theory and the case of Israel. Journal of monetary economics 51: 971-1002. [CrossRef]

El Houri, Walid, and Dima Saber. 2010. Filming resistance: A Hezbollah strategy. Radical History Review 2010: 70-85. [CrossRef]

Eldor, Rafi, and Rafi Melnick. 2004. Financial markets and terrorism. European Journal of Political Economy 20: 367-86. [CrossRef]

Friedman, Brandon. 2018. Iran's Hezbollah Model in Iraq and Syria: Fait Accompli? Orbis 62: 438-53. [CrossRef]

Ghaddar, Hanine. 2017. Saudi Arabia's War on Lebanon. In Policy Abalysis. Washington, DC: Washington Institute.

Gonçalves, Fernando M. 2008. The Optimal Level of Foreign Reserves in Financially Dollarized Economies: The Case of Uruguay. Revista de Economía 15: 35-66. [CrossRef]

Grumet, Tali Rachel. 2015. New Middle East Cold War: Saudi Arabia and Iran's Rivalry. Master's thesis, University of Denver, Denver, CO, USA.

Gupta, Eshita. 2008. Oil vulnerability index of oil-importing countries. Energy Policy 36: 1195-211. [CrossRef]

Gupta, Rangan, Giray Gozgor, Huseyin Kaya, and Ender Demir. 2019. Effects of geopolitical risks on trade flows: Evidence from the gravity model. Eurasian Economic Review 9: 515-30. [CrossRef]

Haddad, Simon. 2006. The origins of popular support for Lebanon's Hezbollah. Studies in Conflict E Terrorism 29: 21-34.

Hamadeh, Mohamad, and Charbel Bassil. 2017. Terrorism, war, and volatility in tourist arrivals: The case of Lebanon. Tourism Analysis 22: 537-50. [CrossRef]

Harding, Don, and Adrian Pagan. 2002. Dissecting the cycle: a methodological investigation. Journal of monetary economics 49: 365-81. [CrossRef]

Hendrix, Cullen S. 2019. Keeping Up with the Future: Upgrading Forecasts of Political Instability and Geopolitical Risk. Washington, DC: Peterson Institute for International Economics.

Illing, Mark, and Ying Liu. 2003. An Index of Financial Stress for Canada. Ottawa: Bank of Canada.

Internal Displacement Monitoring Center IDMC. 2010. Lebanon: No New Displacement But Causes of Past Conflicts Unresolved. Geneva: IDMC, Available online: https://www.internal-displacement.org/countries/lebanon (accessed on 30 December 2010).

Ishrakieh, Layal Mansour, Leila Dagher, and Hariri El Sadika. 2020a. A financial stress index for a highly dollarized developing country: The case of Lebanon. Central Bank Review 20: 43-52. [CrossRef]

Ishrakieh, Layal Mansour, Leila Dagher, and Hariri El Sadika. 2020b. Not the usual suspects: Critical indicators in a dollarized country's Financial Stress Index. Finance Research Letters 32: 101175. [CrossRef]

Jad, Sana Souaid. 2017. Monitoring Business Cycles in Lebanon: Is Economic Growth Cyclical? Is Economic Growth Cyclical? Basel: Bank for International Settlements.

Janine, M. 2018. Russia, Iran and Turkey, a Common Strategy in Syria. Barcelona: Cidob Barcelona Centre For International Affairs. 
Jeanne, Olivier. 2007. International reserves in emerging market countries: too much of a good thing? Brookings Papers on Economic Activity 2007: 1-79. [CrossRef]

Jetter, Michael. 2017. The effect of media attention on terrorism. Journal of Public Economics 153: 32-48. [CrossRef]

Jones, Seth G. 2019. War by Proxy: Iran's Growing Footprint in the Middle East. Washington, DC: Center for Strategic \& International Studies.

Kalb, Marvin, and Carol Saivetz. 2007. The Israeli-Hezbollah war of 2006: The media as a weapon in asymmetrical conflict. Harvard International Journal of Press/Politics 12: 43-66. [CrossRef]

Kaminsky, Graciela L., and Carmen M. Reinhart. 2002. Financial markets in times of stress. Journal of Development Economics 69: 451-70. [CrossRef]

Karamelikli, Huseyin, Ashfak Ahmad Khan, and Mohammad Sharif Karimi. 2020. Is terrorism a real threat to tourism development? Analysis of inbound and domestic tourist arrivals in Turkey. Current Issues in Tourism 23: 2165-81. [CrossRef]

Kuçi, Gurakuç. 2020. Civilization, Ideology and Geopolitics after the Fall of Bismarck with World War I Actors, USA and Russia. JUSTICIA-International Journal of Legal Sciences 8: 101-14.

Lee, Jong-Eun. 2019. The world stock markets under geopolitical risks: Dependence structure. The World Economy 42: 1898-930. [CrossRef]

Liu, Anyu, and Stephen Pratt. 2017. Tourism's vulnerability and resilience to terrorism. Tourism Management 60: 404-17. [CrossRef]

Liu, Jing, Feng Ma, Yingkai Tang, and Yaojie Zhang. 2019. Geopolitical risk and oil volatility: A new insight. Energy Economics 84: 104548. [CrossRef]

Mansour-Ichrakieh, Layal, and Hussein Zeaiter. 2019. The role of geopolitical risks on the Turkish economy opportunity or threat. The North American Journal of Economics and Finance 50: 101000. [CrossRef]

Matusitz, Jonathan. 2018. Brand management in terrorism: the case of Hezbollah. Journal of Policing, Intelligence and Counter Terrorism 13: 1-16. [CrossRef]

May, Samantha. 2020. Faith and Resistance: The Politics of Love and War in Lebanon: By Sarah Marusek, London, Pluto Press, 2018,256 pp.,£ 24.99 (Paperback), ISBN 9780745399928. Abingdon: Taylor \& Francis.

Mendoza, Enrique G., and Marco E. Terrones. 2008. An Anatomy of Credit Booms: Evidence from Macro Aggregates and Micro Data. Cambrideg: National Bureau of Economic Research.

Nilsson, Marco. 2020. Hezbollah and the framing of resistance. Third World Quarterly 41: 1595-614. [CrossRef]

Norton, Augustus Richard. 2007. The role of Hezbollah in Lebanese domestic politics. The International Spectator 42: 475-91. [CrossRef]

Obstfeld, Maurice, Jay C. Shambaugh, and Alan M. Taylor. 2009. Financial instability, reserves, and central bank swap lines in the panic of 2008. American Economic Review 99: 480-86. [CrossRef]

Plakandaras, Vasilios, Rangan Gupta, and Wing-Keung Wong. 2019. Point and density forecasts of oil returns: The role of geopolitical risks. Resources Policy 62: 580-87. [CrossRef]

Reinhart, Carmen M., and Kenneth S. Rogoff. 2009. The aftermath of financial crises. American Economic Review 99: 466-72. [CrossRef]

Saint Akadiri, Seyi, Kayode Kolawole Eluwole, Ada Chigozie Akadiri, and Turgay Avci. 2020. Does causality between geopolitical risk, tourism and economic growth matter? Evidence from Turkey. Journal of Hospitality and Tourism Management 43: 273-77. [CrossRef]

Saiz, Albert, and Uri Simonsohn. 2013. Proxying for unobservable variables with internet document-frequency. Journal of the European Economic Association 11: 137-65. [CrossRef]

Salamey, Imad, and Zanoubia Othman. 2011. Shia revival and welayat al-faqih in the making of Iranian foreign policy. Politics, Religion E Ideology 12: 197-212.

Sandler, Todd, and Walter Enders. 2008. Economic consequences of terrorism in developed and developing countries: An overview. Terrorism, Economic Development, and Political Openness 17: 1-43.

Schmitt, Michael N. 2007. Change Direction 2006: Israeli Operations in Lebanon and the International Law of Self-Defense. Mich. J. Int'l L. 29: 127.

Schrodt, Philip A. 1997. Early Warning of Conflict in Southern Lebanon Using Hidden Markov Models. Washington, DC: American Political Science Association.

Schrodt, Philip A., and Deborah J. Gerner. 1997. Empirical indicators of crisis phase in the Middle East, 1979-1995. Journal of Conflict Resolution 41: 529-52. [CrossRef]

Schrodt, Philip A., and Deborah J. Gerner. 2004. An event data analysis of third-party mediation in the Middle East and Balkans. Journal of Conflict Resolution 48: 310-30. [CrossRef]

Seabra, Claudia, Pedro Reis, and José Luís Abrantes. 2020. The influence of terrorism in tourism arrivals: A longitudinal approach in a Mediterranean country. Annals of Tourism Research 80: 102811. [CrossRef]

Seliktar, Ofira, and Farhad Rezaei. 2020. Hezbollah in Lebanon: Creating the Model Proxy. In Iran, Revolution, and Proxy Wars. Cham: Springer, pp. 21-56.

Sharp, Jeremy M., Christopher Blanchard, Kenneth Katzman, Carol Migdalovitz, Alfred Prados, Paul Gallis, Dianne Rennack, John Rollins, Marjorie Browne, and Steve Bowman. 2006. Lebanon: The Israel-Hamas-Hezbollah Conflict. Washington, DC: Library of Congress Congressional Research Service.

Sheikh, Naveed S. 2003. The New Politics of Islam: Pan-Islamic Foreign Policy in a World of States. London: Routledge.

Škare, Marinko, and Saša Stjepanović. 2016. Measuring business cycles: A review. Contemporary Economics 10: 83-94. [CrossRef] 
Soto, Claudio, and Pablo García. 2004. Large Hoardings of International Reserves: Are They Worth It? Documentos de Trabajo (Banco Central de Chile) 299: 1.

Stock, James H., and Mark W. Watson. 2001. Vector autoregressions. Journal of Economic perspectives 15: 101-15. [CrossRef]

Tavares, José. 2004. Institutions and economic growth in Portugal: A quantitative exploration. Portuguese Economic Journal 3: 49-79. [CrossRef]

Tavares, Jose, and Romain Wacziarg. 2001. How democracy affects growth. European Economic Review 45: 1341-78. [CrossRef]

Tsesis, Alexander. 2017. Terrorist speech on social media. Vand. L. Rev. 70: 651.

United.States.Government. 2019. Treasury Targets Iranian-Backed Hizballah Officials for Exploiting Lebanon's Political and Financial System; Washington, DC: Department of the Treasury.

United.States.Government. 2021. Terrorist Designations and State Sponsors of Terrorism; Edited by Foreign Terrorist Organizations. Washington, DC: Bureau of Counterterrorism.

UNSCOL Office of the United Nations Special Coordinator for Lebanon. 2006. Security Council Resolutions on Lebanon. In S/Res/1559 and S/Res/1701. New York: United Nations: Department of Political and Peacebuilding Affairs. First published 2004.

Vo, Duc Hong, Ha Minh Nguyen, Tan Manh Vo, and Michael McAleer. 2020. Information Sharing, Bank Penetration and Tax Evasion in Emerging Markets. Risks 8: 38. [CrossRef]

Weimann, Gabriel. 2008. Hezbollah Dot Com: Hezbollah's Online Campaign. New Media and Innovative Technologies, 17-38. Available online: https:/ / www.researchgate.net/publication/251393431 (accessed on 23 September 2020).

Wiegand, Krista E. 2009. Reformation of a terrorist group: Hezbollah as a Lebanese political party. Studies in Conflict $\mathcal{E}$ Terrorism 32 : $669-80$.

Worrall, James, Simon Mabon, and Gordon Clubb. 2015. Hezbollah: From Islamic Resistance to Government: From Islamic Resistance to Government. Santa Barbara: ABC-CLIO.

Yarchi, Moran. 2016. Does using 'imagefare'as a state's strategy in asymmetric conflicts improve its foreign media coverage? The case of Israel. Media, War E Conflict 9: 290-305. 